\title{
Microbial hitchhikers on intercontinental dust: catching a lift in Chad
}

\author{
Jocelyne Favet ${ }^{1}$, Ales Lapanje ${ }^{2}$, Adriana Giongo ${ }^{3}$, Suzanne Kennedy ${ }^{4}$, Yin-Yin Aung ${ }^{1}$, \\ Arlette Cattaneo ${ }^{1}$, Austin G Davis-Richardson ${ }^{3}$, Christopher T Brown ${ }^{3}$, Renate Kort ${ }^{5}$, \\ Hans-Jürgen Brumsack ${ }^{6}$, Bernhard Schnetger ${ }^{6}$, Adrian Chappell7, Jaap Kroijenga ${ }^{8}$, \\ Andreas Beck ${ }^{9,10}$, Karin Schwibbert ${ }^{11}$, Ahmed H Mohamed ${ }^{12}$, Timothy Kirchner ${ }^{12}$, \\ Patricia Dorr de Quadros ${ }^{3}$, Eric W Triplett ${ }^{3}$, William J Broughton ${ }^{1,11}$ and
} Anna A Gorbushina ${ }^{1,11,13}$

${ }^{1}$ Université de Genève, Sciences III, Genève 4, Switzerland; ${ }^{2}$ Institute of Physical Biology, Ljubljana, Slovenia; ${ }^{3}$ Department of Microbiology and Cell Science, Institute of Food and Agricultural Sciences, University of Florida, Gainesville, FL, USA ${ }^{4}$ MO BIO Laboratories Inc., Carlsbad, CA, USA; ${ }^{5}$ Elektronenmikroskopie, Carl von Ossietzky Universität, Oldenburg, Germany; ${ }^{6}$ Microbiogeochemie, ICBM, Carl von Ossietzky Universität, Oldenburg, Germany; ${ }^{7}$ CSIRO Land and Water, Black Mountain Laboratories, Black Mountain, ACT, Australia; ${ }^{8}$ Konvintsdyk 1, Friesland, The Netherlands; ${ }^{9}$ Botanische Staatssammlung München, Department of Lichenology and Bryology, München, Germany; ${ }^{10}$ GeoBio-Center, Ludwig-Maximilians Universität München, München, Germany; ${ }^{11}$ Bundesanstalt für Materialforschung, und -prüfung, Abteilung Material und Umwelt, Berlin, Germany; ${ }^{12}$ Geomatics SFRC IFAS, University of Florida, Gainesville, FL, USA and ${ }^{13}$ Freie Universität Berlin, Fachbereich Biologie, Chemie und Pharmazie \& Geowissenschaften, Berlin, Germany

\begin{abstract}
Ancient mariners knew that dust whipped up from deserts by strong winds travelled long distances, including over oceans. Satellite remote sensing revealed major dust sources across the Sahara. Indeed, the Bodélé Depression in the Republic of Chad has been called the dustiest place on earth. We analysed desert sand from various locations in Chad and dust that had blown to the Cape Verde Islands. High throughput sequencing techniques combined with classical microbiological methods showed that the samples contained a large variety of microbes well adapted to the harsh desert conditions. The most abundant bacterial groupings in four different phyla included: (a) Firmicutes-Bacillaceae, (b) Actinobacteria-Geodermatophilaceae, Nocardiodaceae and Solirubrobacteraceae, (c) Proteobacteria-Oxalobacteraceae, Rhizobiales and Sphingomonadaceae, and (d) Bacteroidetes-Cytophagaceae. Ascomycota was the overwhelmingly dominant fungal group followed by Basidiomycota and traces of Chytridiomycota, Microsporidia and Glomeromycota. Two freshwater algae (Trebouxiophyceae) were isolated. Most predominant taxa are widely distributed land inhabitants that are common in soil and on the surfaces of plants. Examples include Bradyrhizobium spp. that nodulate and fix nitrogen in Acacia species, the predominant trees of the Sahara as well as Herbaspirillum (Oxalobacteraceae), a group of chemoorganotrophic free-living soil inhabitants that fix nitrogen in association with Gramineae roots. Few pathogenic strains were found, suggesting that African dust is not a large threat to public health.

The ISME Journal (2013) 7, 850-867; doi:10.1038/ismej.2012.152; published online 20 December 2012

Subject Category: microbial ecology and functional diversity of natural habitats

Keywords: aeolian; high throughput sequencing; Bodélé Depression; Republic of Chad; wind erosion
\end{abstract}

\section{Introduction}

Deserts are the major source of air-borne dust (Prospero et al., 2005; Collaud Coen et al., 2003;

Correspondence: WJ Broughton, Bundesanstalt für Materialforschung, und -prüfung, Abteilung Material und Umwelt, Unter den Eichen 87, 12205 Berlin, Germany.

E-mail: williamebroughton@gmail.com

Received 16 July 2012; revised 22 October 2012; accepted 27 October 2012; published online 20 December 2012 see also Gorbushina et al., 2007). 1000-3000 $\times 10^{6}$ tonnes (Mt) of desert soil (convergence value $\sim 2000$ Mt-Shao, 2008) travel long distances on winds each year (Caquineau et al., 1998; Shao et al., 2011). Of this total, $130-760 \mathrm{Mt}$ originate from the Sahara (for example, Alfaro et al., 1998; Callot et al., 2000; Middleton and Goudie, 2001 and Shao, 2008). About three-quarters of this dust falls back to land in Africa: most of the rest into oceans. By analysing Total Ozone Mapping Spectrometer data, Middleton and Goudie (2001) and Goudie and Middleton, 
(2001, 2006) showed that the major African dust sources include southern Algeria, western Mali, eastern Mauritania and the Bodélé Depression. The latter is located at the southern edge of the Sahara Desert, is the lowest point in Chad, was the floor of a much larger Mega-Lake Chad and has been called 'the dustiest place on earth' (Giles, 2005; Engelstaedter et al., 2006; Warren et al., 2007). Winds that sweep between the Tibesti and the Ennedi mountains in northern Chad are funnelled across this depression.

Over the past 10000 years, northern Africa has changed from 'green' to a hot desert (Kröpelin et al, 2008). Persistent droughts, coupled with increased demand for irrigation, reduced Lake Chad to about five per cent of its original area (Drake and Bristow, 2006). As Mega-Lake Chad receded to the current position of Lake Chad, diatoms sedimented from the fresh water and now form the surface crust. The silts and sediments dried on the lake bed and it is from here that the coupled saltation/sand blasting processes heave crust particles into the air. During the northern winter, the depression produces an average of 700000 tonnes dust/day (Koren et al., 2006).

Dust storms over the Atlantic are part of seafaring lore. Charles Darwin and his friend Christian Ehrenberg showed that airborne dust contains organic material (Darwin, 1846). Microbes that hitchhike on desert dust are now known to spread across the globe (Griffin et al., 2003a, b; Kellog et al., 2004; Prospero et al., 2005; Kellogg and Griffin, 2006; Weir-Brush et al., 2004; Lim et al., 2011). Gorbushina et al. (2007) used geochemical methods to show that the Darwin/ Ehrenberg dust probably originated from the Sahara.

As microbes need a dust-like vehicle to travel long distances (Yamaguchi et al., 2012), those microorganisms that are present in desert soils at the source of dust events are blown into the stratosphere and across continents. Surface soils of the deserts of the Republic of Chad (afterwards Chad) are an obvious place to study microbes before they begin intercontinental travel. Sand samples from Bardaï in the desert zone to the northwest of the country and others from the arid Sahelian belt in the east (Bahaï Wadii, Oure Cassonia, Vers Ourba and Vers Iriba) were collected by the International Committee of the Red Cross. One of the authors (AC) provided dust samples from the Bodélé Depression (Warren et al., 2007 and Chappell et al., 2008), whereas AAG, JP and WJB collected dust during a remake of Darwin's Beagle voyage in 2009. Here we catalogue the microbiological contents of these samples using classic techniques, metagenomic methods and high throughput sequencing (HtS) specially developed to reveal uncultivable microorganisms that adhere to dust (Giongo et al., 2012).

\section{Materials and methods}

\section{The samples}

Three sets of samples were analysed: I sand from various regions of Chad (Table 1); II dust collected from the Bodélé Depression in Chad (Table 2) and III dust harvested on board the 'Stad Amsterdam' (Table 3)(Figure 1). Isolation of algae, bacteria and fungi, the extraction of DNA from sand/dust, DNA sequencing, geochemical analyses as well as scanning electron microscopy were performed exactly as described in Giongo et al. (2012). Nitrifying bacteria were isolated according to MacFarlane and Herbert (1984). Since samples II were restricted in size and samples III were vanishingly small, we only sought cultivable microbes and performed partial geochemical analyses on them.

\section{Statistical analyses}

To test whether the distributions of microbes were affected by geographic and/or geochemical factors, the presence of the 40 most abundant families were transformed $\left(\log _{10}\right)$, Spearman correlation matrices created (alpha $=0.01)$ and principal component

Table 1 Coordinates and description of the sand collected from Chad

\begin{tabular}{|c|c|c|c|c|c|c|}
\hline Location & Collector $^{\mathrm{a}}$ & Date collected & Latitude & Longitude & Altitude (m) & Description \\
\hline C1 Bardaï & CICR & 2007 & N21.21.999 & E17.03.202 & 1105 & Large, multi-coloured grains $2-3 \mathrm{~mm}$ \\
\hline C2 Bardaï & CICR & 2007 & N21.21.999 & E17.03.202 & 1105 & Fine, red sand \\
\hline C3 Bahaï Wadi I & Sandman B & 30.04 .07 & N15.37.473 & E23.00.626 & 781 & Clumped, red-brown sand \\
\hline C4 Bahaï Wadi II & Sandman C & 30.04 .07 & N15.37.473 & E23.00.626 & 781 & Fine, ochre-coloured, flowing sand \\
\hline C5 Oure Cassonia & Sandman A & 30.04 .07 & N15.40.215 & E23.02.247 & 797 & Fine $1-2 \mathrm{~mm}$, red sand \\
\hline C6 near Ourba & Sandman D2 & 01.05 .07 & N15.23.905 & E22.42.297 & 836 & Fine $1-2 \mathrm{~mm}$, red sand \\
\hline C7 near Iriba & Sandman G & 01.05 .07 & N15.20.080 & E22.24.634 & 898 & Fine $1-2 \mathrm{~mm}$, red sand, with large, white grains \\
\hline C8 near Ourba & Sandman D1 & 01.05 .07 & N15.23.905 & $\mathrm{E} 22.42 .297$ & 836 & Fine $1-2 \mathrm{~mm}$, red sand, some clumps \\
\hline C9 near Ourba & Sandman F & 01.05 .07 & N15.23.648 & E22.30.953 & 895 & Fine $1-2 \mathrm{~mm}$, red sand, with large, white grains \\
\hline
\end{tabular}

where: altitude is above sea level.

aSampling was organised by Dr. Agathe Stricker of the Comité international de la Croix Rouge (CICR), Genève, Switzerland from various locations in the Republic of Chad. As the actual collectors wish to remain anonymous, they have been listed either as CICR or Sandman the 'nom de plume' that the collectors themselves suggested. C1 and C2 were collected in Bardaï, a small oasis town (and garrison) in the Bourkou-Ennedi-Tibesti Region near the Tibesti Mountains (a group of largely inactive volcanoes) in the Central Saharan Desert. All other samples were collected in Eastern Chad. C4 was from Bahaï-Wadi II near Iriba, a town in the Wadi Fira Region. Samples C6, C8 and C9 were taken near Ourba a gathering place close to the city of Biltine, the capital of the Wadi Fira region. Sample C7 was from a refugee camp near Iriba, the main town in the Department of Kobé in the region of Wadi Fira. All samples were aseptically scraped directly in $50 \mathrm{ml}$ Falcon tubes for storage and transport. 
Table 2 Dust collected during the BodEx expedition at different heights above the desert surface

\begin{tabular}{|c|c|c|c|c|c|c|}
\hline Sample \# & Collector & Date collected & Latitude & Longitude & Altitude (asl) \& height & Description \\
\hline Wp 44 Bodélé near Chica & see Chappell et al. (2008) & $\begin{array}{c}10.03 .05 \text { to } \\
12.03 .05\end{array}$ & N16.52.53 & E18.32.548 & $179 \mathrm{~m}$ & surface \\
\hline Wp 45 Bodélé near Chica & see Chappell et al. (2008) & $\begin{array}{c}10.03 .05 \text { to } \\
12.03 .05\end{array}$ & N16.52.53 & E18.32.548 & $179 \mathrm{~m} 0.75 \mathrm{~m}$ & dust bottom \\
\hline Wp 58 Bodélé near Chica & see Chappell et al. (2008) & $\begin{array}{c}10.03 .05 \text { to } \\
12.03 .05\end{array}$ & N16.58.5353 & E18.28.036 & $179 \mathrm{~m} 2.4 \mathrm{~m}$ & dust top \\
\hline
\end{tabular}

where: altitude is above sea level and height above the desert surface. The multi-disciplinary Bodélé Field Experiment (BoDEx 2005-http:// www.geog.ox.ac.uk/research/climate/projects/bodex/index.html.) took place from February 28 to March 13, 2005 at a site called 'Chicha' (16 53 ' $\mathrm{N}, 18^{\circ} 33^{\prime} \mathrm{E} ; 179 \mathrm{~m}$ asl) at the eastern margin of a large diatomite deposit that originated from Mega-Lake Chad (see Warren et al., 2007; Chappell et al., 2008). Samples were collected in a narrow corridor of desert pavement on the eastern edge of the sand sea of the Erg d'Djourab and the far eastern margin of the massive diatomite surface of paleo Lake Chad ( $16^{\circ} 52^{\prime} 53^{\prime \prime} \mathrm{N} 18^{\circ} 32^{\prime} 54.8^{\prime \prime} \mathrm{E}$ and $\left.16^{\circ} 58^{\prime} 53^{\prime \prime} \mathrm{N} 18^{\circ} 28^{\prime} 03.6^{\prime \prime} \mathrm{E}\right)$. One of the authors (AC) took part in the BodEx expedition and provided three samples—a 'grab' sample of the surface material comprising mobile sediment overlying the diatomite playa (Wp 44), dust collected at $0.75 \mathrm{~m}$ above the surface during a dust storm (Wp 45 ) and dust collected at $2.4 \mathrm{~m}$ above the desert surface during the same storm (Wp 58). At the time of analysis, the samples had been stored for three years and had been X-rayed twice by custom officials during transportation from the Republic of Chad to the UK and from the UK to Switzerland.

Table 3 Dust samples collected on board the 'Stad Amsterdam'

\begin{tabular}{|c|c|c|c|}
\hline Sample & Location & Place & Date \\
\hline Ft1 to Ft4 & $\begin{array}{l}\text { Ilha de Santiago, leaving port } \\
14^{\circ} 07^{\prime} 13^{\prime \prime} \mathrm{N} 23^{\circ} 43^{\prime} 65^{\prime \prime} \mathrm{W}\end{array}$ & $\begin{array}{l}\text { Mizzen mast, } \approx 20 \mathrm{~m} \text { asl. Ft1 }-\mathrm{P}, \mathrm{Ft} 2-\mathrm{A} \\
\text { Ft3 }-\mathrm{F} ; \mathrm{Ft} 4-\mathrm{S}^{*} \text {. }\end{array}$ & 22.09-23.09.2009 \\
\hline Ft5 to Ft8 & 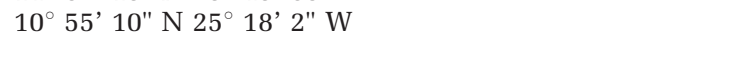 & $\begin{array}{l}\text { Mainmast, } \approx 20 \mathrm{~m} \text { asl. Ft5 }-\mathrm{SA}, \mathrm{Ft} 6-\mathrm{SF} \text {, } \\
\text { Ft7 - PA, Ft8 - PF. }\end{array}$ & $23.09-25.09 .2009$ \\
\hline Alu M & $10^{\circ} 55^{\prime} 10^{\prime \prime} \mathrm{N} 25^{\circ} 18^{\prime} 2^{\prime \prime} \mathrm{W}$ & Mainmast & $23.09-25.09 .2009$ \\
\hline Alu A & $\begin{array}{l}\text { Ilha de Santiago, leaving port } \\
14^{\circ} 07^{\prime} 13^{\prime \prime} \mathrm{N} 23^{\circ} 43^{\prime} 65^{\prime \prime} \mathrm{W}\end{array}$ & Toilet roof (starboard/windward side) & $22.09-23.09 .2009$ \\
\hline Alu2 (Control) & $\begin{array}{l}\text { At sea between Arquipélago de São Pedro e } \\
\text { São Paulo } 00^{\circ} 55^{\prime} 1^{\prime \prime} \mathrm{N} 29^{\circ} 20^{\prime} 7^{\prime \prime} \mathrm{W} \text { \& Fernando de Noronha } \\
3^{\circ} 51^{\prime} \mathrm{S}, 32^{\circ} 25^{\prime} \mathrm{W}\end{array}$ & Toilet roof (port/leeward side) & $26.09-27.09 .2009$ \\
\hline Alu B & $\begin{array}{l}\text { Ilha de Santiago, leaving port } \\
14^{\circ} 07^{\prime} 13^{\prime \prime} \mathrm{N} 23^{\circ} 43^{\prime} 65^{\prime \prime} \mathrm{W}\end{array}$ & Toilet roof (port/leeward side) & $22.09-23.09 .2009$ \\
\hline Alu4 (Control) & $\begin{array}{l}\text { At sea between Arquipélago de São Pedro e } \\
\text { São Paulo } 00^{\circ} 55^{\prime} 1^{\prime \prime} \mathrm{N} 29^{\circ} 20^{\prime} 7^{\prime \prime} \mathrm{W} \text { \& Fernando de Noronha } \\
3^{\circ} 51^{\prime} \mathrm{S}, 32^{\circ} 25^{\prime} \mathrm{W}\end{array}$ & Toilet roof (starboard/windward side) & $26.09-27.09 .2009$ \\
\hline \multicolumn{4}{|c|}{ 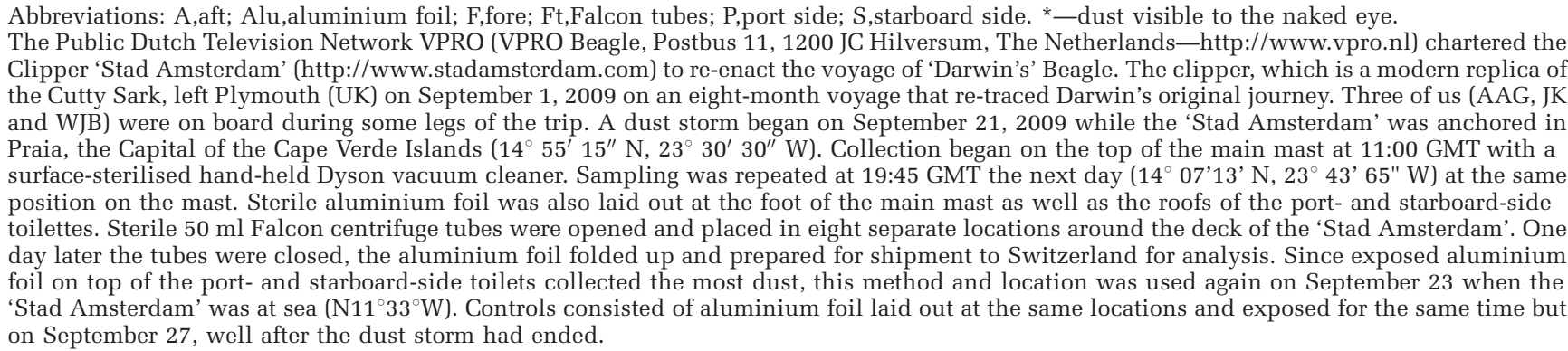 } \\
\hline
\end{tabular}

analyses (using XLSTAT2011 software) performed on the transformed correlation matrices (Addinsoft, New York, NY, USA).

\section{Results}

\section{Geochemistry}

Sand was analysed for both major and trace elements (see Figure 2a, b). Dust from the Bodélé
Depression was only analysed for major elements. With the exception of C3 (64 weight (wt) \%), all sand samples contained at least $85 \mathrm{wt} \% \mathrm{SiO}_{2}$ (in wt \% respectively: C1 93; C2 85; C4 95; C5 89; C6 87; C7 87; C8 92 and C9 89). Mineral contents varied widely and without association with location (for example, $\mathrm{Fe}$ ). Sample $\mathrm{C} 4$ contained 0.2 wt $\% \mathrm{Fe}_{2} \mathrm{O}_{3}$, whereas C3 had more than 5.2 wt \% (median around 3 wt \%) (see Bristow et al., 2010). Consequently, correlations between geographical location and Fe 


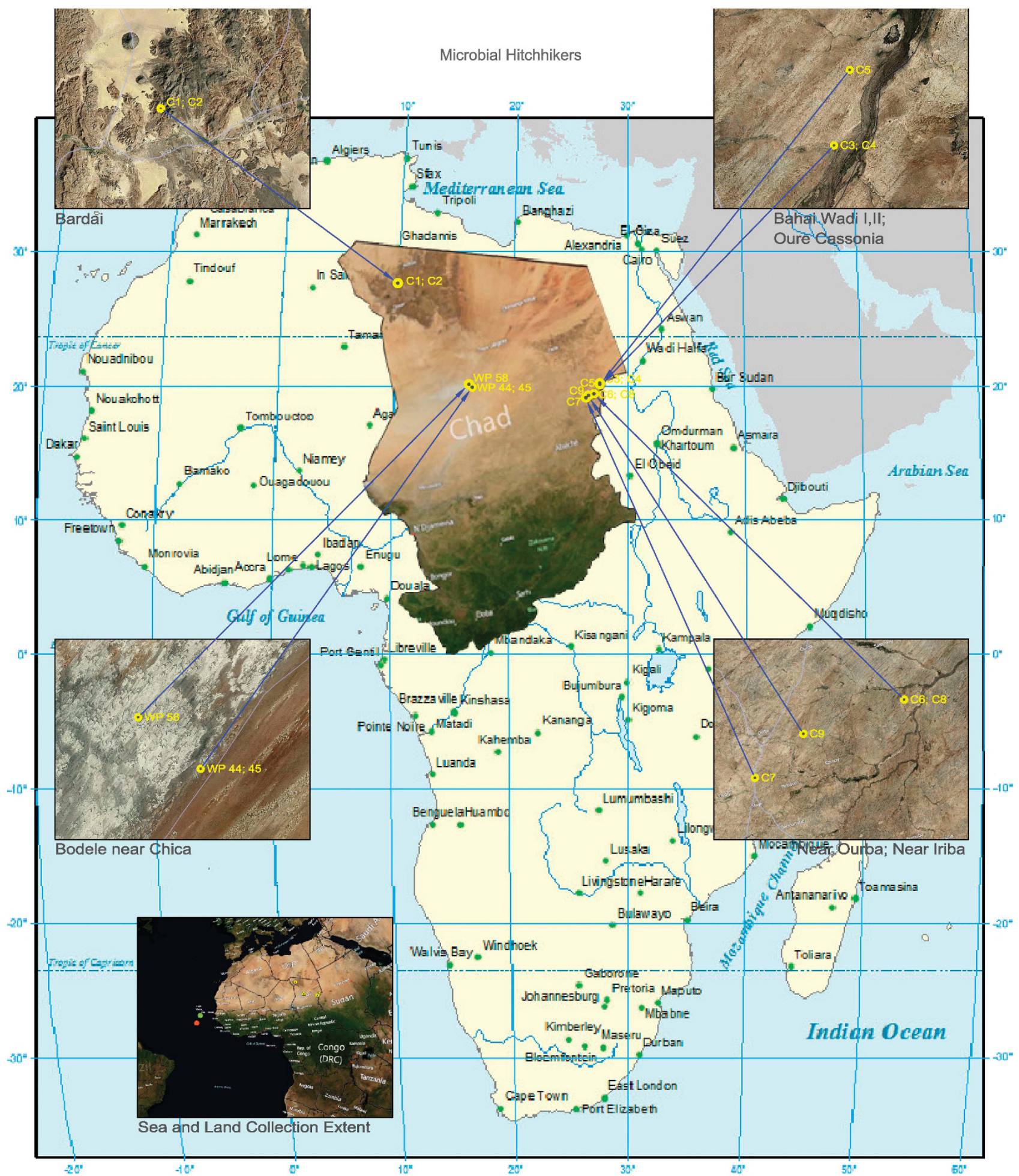

Figure 1 Map of Africa with insets showing the dust/sand collection sites in the Republic of Chad and the Cape Verde Islands. Abbreviations C1-C9 represent the sand collection sites in Chad (see Table 1). WP44, WP45 and WP58 show those in the Bodélé Depression (Table 2) whereas insert (e) shows the positions of the 'Stad Amsterdam' near the Cape Verde Islands during the storm in which dust was collected (Table 3).

content could not be drawn (vide infra). The scarcity of phosphorus was particularly striking: none was found in C4 and C7 whereas C1 contained only 0.002 wt \%. C3 had significantly larger values $(0.13$ wt \%) and Bodélé dust was enriched in $\mathrm{P}$ (between 0.06 and 0.09 wt \%). Similarly, C3 had higher values of $\mathrm{Al}, \mathrm{Fe}, \mathrm{K}$ and $\mathrm{P}$ than the other samples. Zirconium was the most abundant metal: concentrations ranged 
854

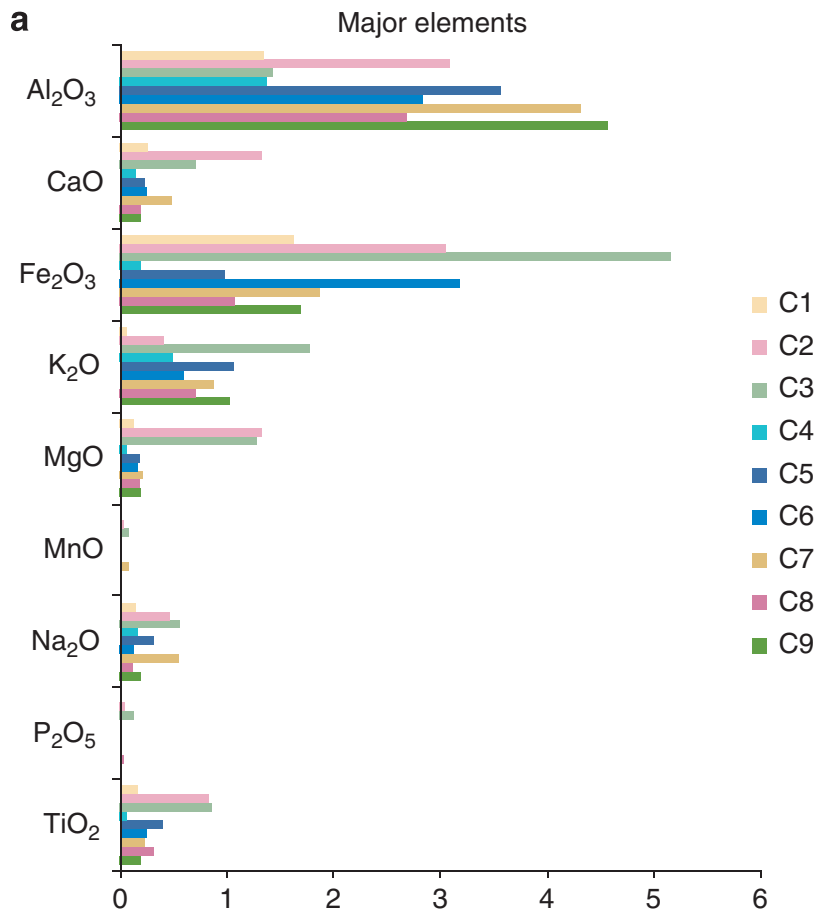

b

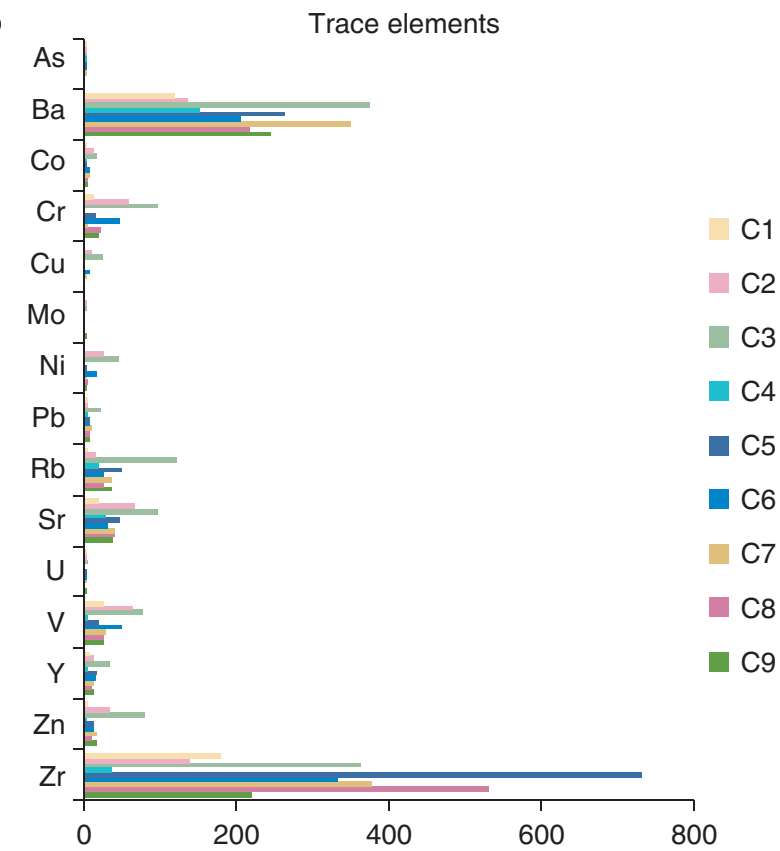

Figure 2 Elemental analyses of desert material collected from the Republic of Chad. (a) Major elements are listed in weight per cent, (b) Trace elements in $\mathrm{mg} \mathrm{kg}^{-1}$.

from $\sim 40 \mathrm{mg} \mathrm{kg}^{-1}$ (C4) to $730 \mathrm{mg} \mathrm{kg}^{-1}$ (C5). Variation in the levels of barium, the next most abundant metal, was much less (from $120 \mathrm{mg} \mathrm{kg}^{-1}$ in C1 to $350 \mathrm{mg} \mathrm{kg}^{-1}$ in C7).

Increased elemental loads in dust can be explained by fractionation of soils and sediments during transport by wind. Strong winds are known to enrich dust with $\mathrm{Zr}$, but it is also possible that the rocks from which the sand/dust originated, contained granites that are known to have high zircon contents.

\section{Microscopic structure}

SEM showed, with the exception of C3, that the nonrehydrated samples were a collection of loose grains to which small particles adhered (Figure 3). Under these in situ conditions, it was difficult to distinguish microbes from particles of clay, diatom fragments and other adhering material. Nevertheless, obvious cellular structures, often residing in surface irregularities that offer microbes dwelling spaces, were visible (Figure 3). C2 is representative of most samples and clearly shows rounded grains produced by wind erosion (Figure 3a). Enlargement (Figure $3 \mathrm{~b}$ ) revealed the surface irregularities and encrustation that is typical of all samples (cf Chappell et al., 2008). Fragments of diatom shells can be seen in close-ups (for example, Figure 3c). As both Figure 3a and Figure $3 \mathrm{~d}$ are reproduced at the same magnification, the difference between loose grains (in all other samples) and the surface crust in C3 is readily apparent. Other noteworthy features include: many, diverse particles that closely resemble fragments formed by wind in C4 (Figure 3e); a bacterial colony on the surface of a depression in the grain of C5 (Figure 3f); an encrusted microbial filament on the surface of the sand grain in Figure 3g (C6) and; a branching fungal hyphae in close contact with the sand grain surface as well as particulate matter held together by a slimy matrix (Figure 3h-C5).

\section{Microbes in Chad sand}

Two different HtS techniques were used: with all the samples except C3 and C5, DNA was extracted from the sand or dust, amplified using primers for $16 \mathrm{~S}$ rRNA genes and the products subjected to HtS. With samples C3 and C5, the isolated DNA was directly sequenced (see Giongo et al., 2012). Except for C3 and C5, where classified reads (read $=\mathrm{a}$ single, unedited, machine-generated DNA sequence) were used, the results are given in per cent of total reads. The number of reads obtained varied widely: C1 gave only 351; C2 yielded 26239; C4 89811; C6 98718 ; C7 50945; C8 159088 and C9 30077 (classified reads for C3 and C5 were 5136 and 5319 respectively). Despite the $>70$-fold smaller numbers of reads obtained for $\mathrm{C} 1$ and $\mathrm{C} 2$, numerous genera that were present in these samples were absent in samples C3-C9.

\section{Phylum actinobacteria}

Forty-nine families were identified, some of which were present in most samples, but their numbers varied greatly. Supplementary Table 1 lists those families comprising $\geqslant 0.3 \%$ of total reads and the seven most abundant families are shown in 

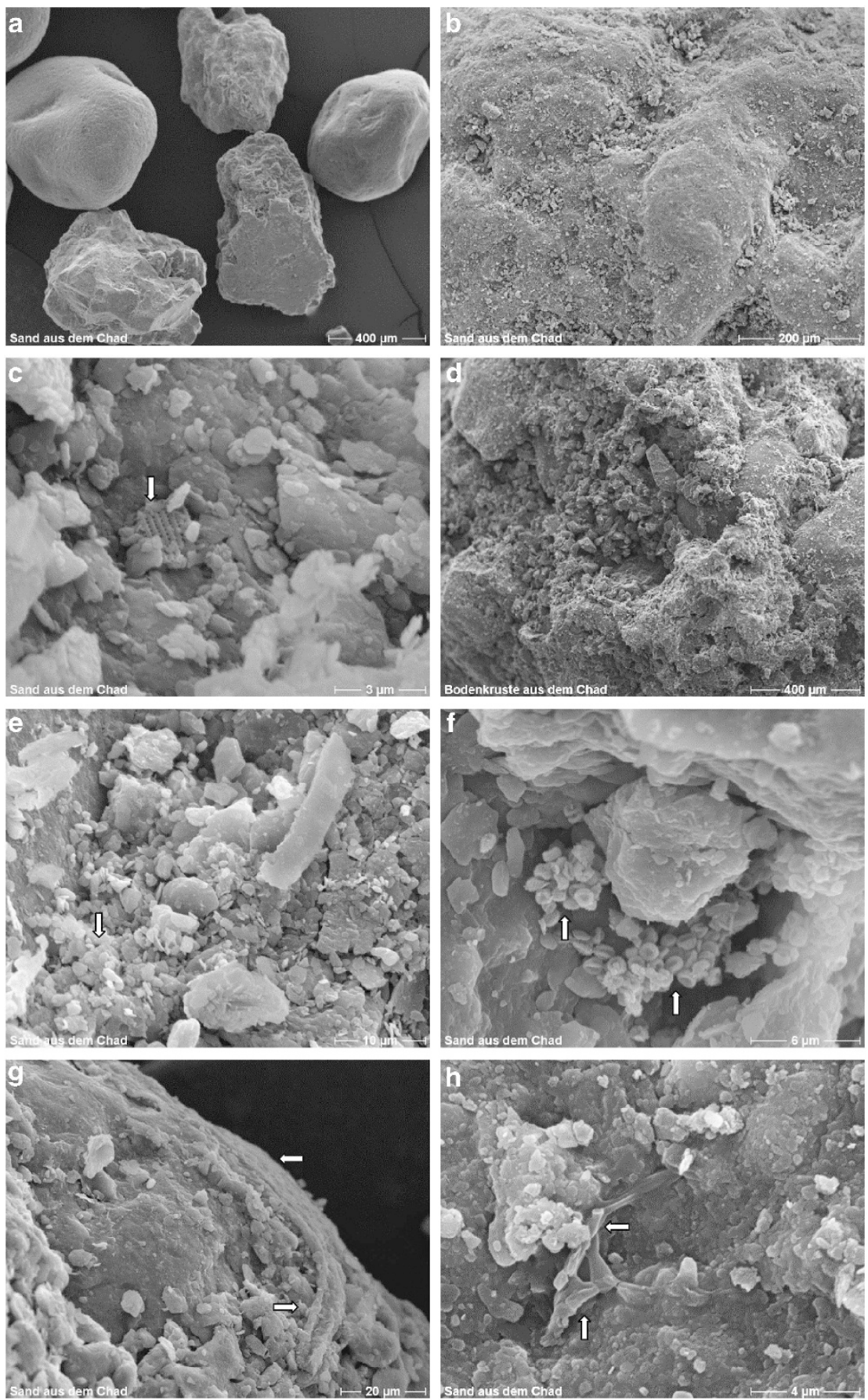

Figure 3 SEM micrographs of air-dried samples of surface material from Chad: Panel $(\mathbf{a})=\mathrm{C} 2 ;(\mathbf{b})=\mathrm{C} 1 ;(\mathbf{c})=\mathrm{C} 1 \mathrm{magnified}$; $(\mathbf{d})=\mathrm{C} 3$; $(\mathbf{e})=\mathrm{C} 4 ;(\mathbf{f})=\mathrm{C} 5 ;(\mathbf{g})=\mathrm{C} 6$ and $(\mathbf{h})=\mathrm{C} 5$. Except for C3, where sand particles were held together by a thick layer of biological material, all other samples were collections of separate sand grains. A great variety of particulate matter can be seen attached to the grains: fragments of diatom shells (arrow) in (c); clumped microbial cells (arrow) in (e); collapsed microbial cells (possibly Archea - arrows in (f); mineralencrusted microbial filaments (possibly fungal hyphae) in (g) and branched fungal hyphae (arrows) in (h). Different ratios of particulate to biogenic matter and sand grains can be seen in D, where the grains in sample C3 seem to be 'cemented together' into a surface crust (cf samples C2 (a) and (b) (C1)).

Figure 4a. Many members of these families are thermophilic, others produce antibiotics and all are widespread in soils. Due to the high abundance of digestive tract bacteria (Bifidobacteriaceae), C1 was strikingly different from the other samples, whereas the other six families were abundant in all samples.

\section{Phylum Firmicutes}

Twenty-eight families of Firmicutes were identified but their presence in individual samples varied greatly (Supplementary Table 2 lists families that make up $\geqslant 0.5 \%$ of the total reads). The seven most abundant families are presented in Figure $4 \mathrm{~b}$. 

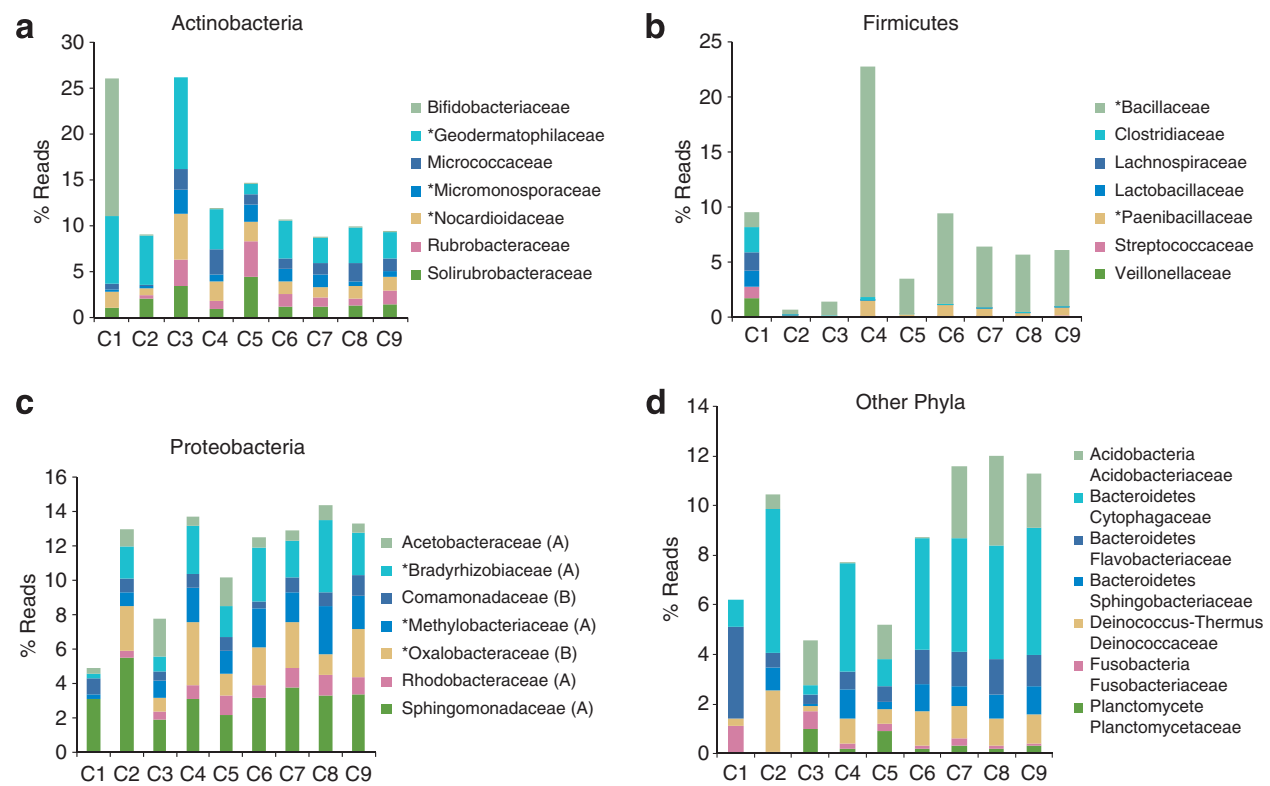

Figure 4 (a) The seven most abundant families of the Phylum Actinobacteria found in the sands of Chad as revealed by HtS (Actinobacterial families making up $\geqslant 0.3 \%$ of the total 'reads' are listed in Supplementary Table 1). Families marked with an asterisk were also found by culture-based methods. Note that the composition of C1 is markedly different from the other samples-more than $50 \%$ of the Actinobacteria are Bifidobacteriaceae (anaerobic bacteria of the gastrointestinal tract and vagina), that along with the many Enterobacteriaceae in this sample, undoubtedly came from the large military force garrisoned nearby. (b) HtS based-data showing the seven most dominant families of the Phylum Firmicutes. Families marked with an asterisk were also found by culture-based methods (Supplementary Table 2 lists those families that comprise $\geqslant 0.5 \%$ of the total 'reads'). Again it is obvious that the bacterial composition of C1 differs markedly from the others. Significant numbers of Clostridiaceae (anaerobic to oxygen-tolerant spore-forming bacilli found in soil as well as in normal intestinal flora of animals), Lachnospiraceae (colon inhabitants), Lactobacillaceae (gastrointestinal tract), Streptococcaceae (widely distributed) and Veillonellaceae (gastrointestinal tract) were found. Undoubtedly, their presence is due to human activity nearby. (c) HtS based-data showing the seven most dominant families of the Phylum Proteobacteria. Families marked with an asterisk were also found by culture-based methods (Supplementary Table 3 lists those families that comprise $\geqslant 0.3 \%$ of the total 'reads'). Note that two families that were fairly abundant in samples C2 to C9 were not found in C1. The most prominent of these were the Oxalobacteraceae (that includes the soil/rhizosphere inhabitants Duganella, Herbaspirillum, Naxibacter, Oxalicibacterium and Telluria). Herbaspirillum seropedicae is a well-studied nitrogen-fixing bacterium. Rhodocacteraceae (non-sulphur, purple, photoheterotrophic bacteria) were also noticeably absent. (d) HtS based-data showing the other seven predominant phyla/families apart from those listed in Figure 4 A-C that make up $\geqslant 0.3 \%$ of the total 'reads' in Chad sand (further details are given in Supplementary Table 4). Here again, the bacterial composition of C1 was noticeably different from the rest. Acidobacteria, a widespread and diverse group of mostly soil inhabitants; the Sphingobacteriaceae comprising three genera of environmental bacteria (Mucilaginibacter, Pedobacter and Sphingobacterium) and the Planctomycetaceae, soil and water (both fresh and hyper-saline) bacteria were not detected.

Bacillaceae dominate in eight of the nine samples comprising $>5 \%$ of the reads in $\mathrm{C} 4$, C6, C7, C8 and C9. Despite the small number of reads obtained, C1 was notably different with $0.1 \%$ Enterococcaceae and $\geqslant 1 \%$ Clostridiaceae, Lachnospiraceae, Lactobacillaceae and Veillonellaceae.

\section{Phylum Proteobacteria}

Comprising representatives of 71 families, the Proteobacteria was the most important phylum of bacteria found (Supplementary Table 3, Figure 4c). All divisions were represented: $\alpha$-Proteobacteria (22 families); $\beta$-Proteobacteria (11 families); $\gamma$-Proteobacteria (18 families); $\delta$-Proteobacteria (17 families); $\varepsilon$-Proteobacteria (2 families), Campylobacteraceae (traces in C8 and C9), Helicobacteraceae (traces in C8) and $\zeta$-Proteobacteria (traces of Mariprofundaceae in C6).

Some families were abundant in almost every sample: Bradyrhizobiaceae, Methylobacteriaceae and
Sphingomonadaceae ( $\alpha$-Proteobacteria) and Oxalobacteraceae ( $\beta$-Proteobacteria) for example. Other families were less abundant but well distributed. Less numerous families $(<0.3 \%)$ included: Bacteriovoraceae $(\delta)$; Bdellovibrionaceae $(\delta)$; Coxiellaceae $(\gamma)$; Erythrobacteriaceae $(\alpha)$; Legionellaceae $(\gamma)$; Methylocystaceae $(\alpha)$; Methylophilaceae $(\beta)$; Neisseriaceae $(\beta)$; Nitrosomonadaceae $(\beta)$; Pasteurellaceae $(\gamma)$; Phaselicystidaceae $(\delta)$; Phyllobacteriaceae $(\alpha)$; Polyangiaceae $(\alpha)$; Rhodobiaceae $(\alpha)$; Rhodocyclaceae $(\beta)$; Rickettsiaceae $(\alpha)$; Sinobacteriaceae $(\gamma)$ and Xanthobacteraceae $(\alpha)$.

\section{Other phyla}

Low numbers of 18 other phyla were also found (Supplementary Table 4, Figure 4d)—two Archaea: Crenarchaeota (Desulfurococcaceae in C7; Sulfolobaceae in C4 and Thermofilaceae in C5) and Euryarchaeota (Methanothermaceae in C5). Acidobacteria comprising three families, Bacteroidetes 
(three dominant families), Deinococcus-Thermus (2), Fusobacteria (1) and Planctomycetes (1).

\section{Fungi}

Ascomycota were overwhelmingly dominant followed by Basidiomycota with traces of Chytridiomycota, Microsporidia and Glomeromycota (Figure 5).

\section{Ascribing 'reads' to genera}

About 1 in 10000 reads could be ascribed to a genus in 13 phyla yielding 453 genera (Table 4). Actinobacteria were both well distributed and abundant. Blastococcus, Geodermatophilus (both Geodermatophilaceae); Arthrobacter (Micrococcaceae); Nocardioides (Nocardioidaceae); Rubrobacter (Rubrobacteraceae) and Solirubrobacter
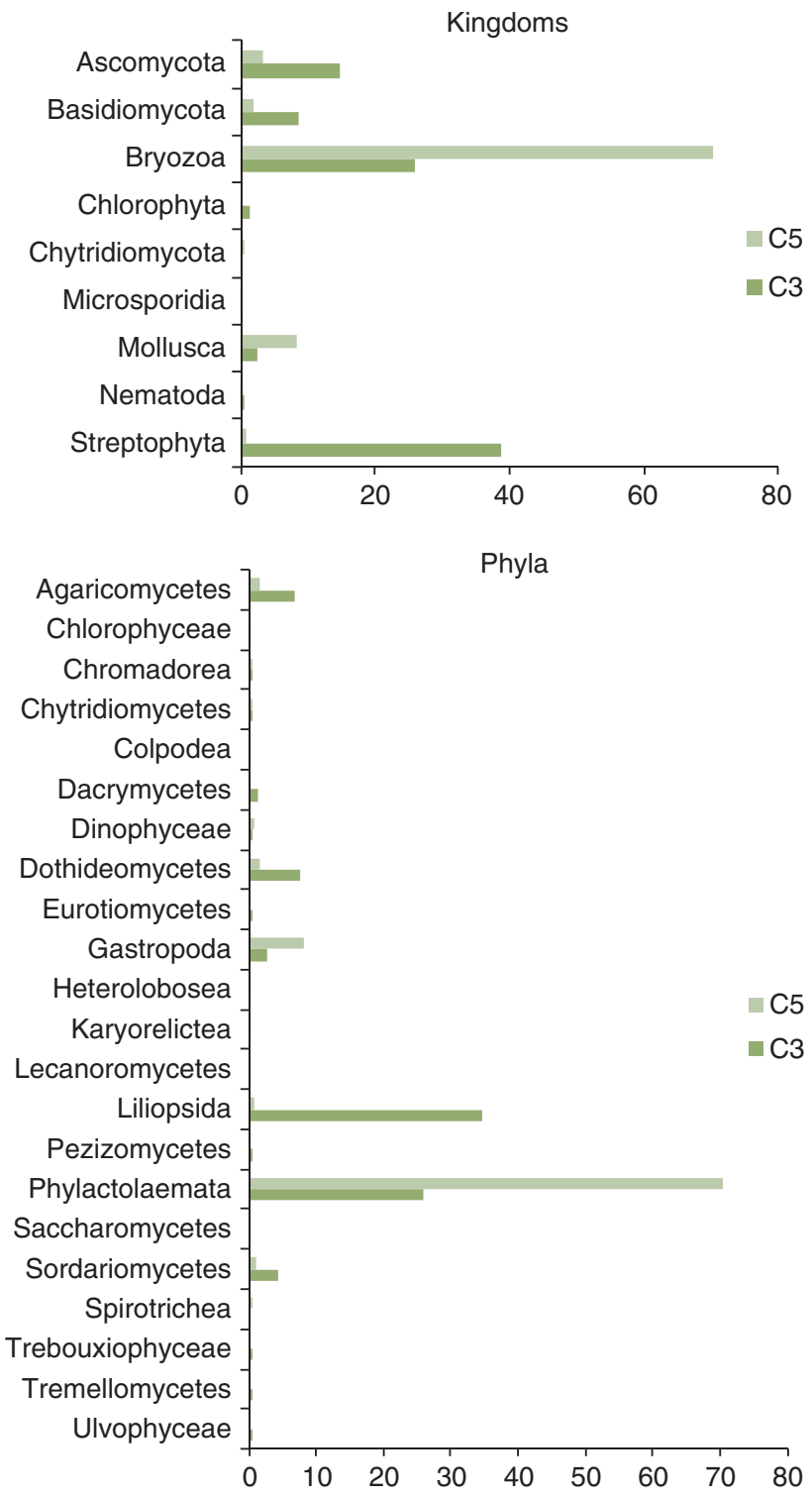

Figure 5 Kingdoms and phyla of Eukaryotes found in samples C3 and C5 by direct HtS methods.
(Solirubrobacteraceae) were the principal genera found. Other well-distributed genera included: Actinoplanes, Cellulomonas, Conexibacter, Modestobacter, Iamia, Kineococcus, Kineosporia, Kocuria, Marmoricola, Micromonospora, Pseudonocardia and Streptomyces.

Bacillus was the principal genus of the Firmicutes $(\%$ reads in $\mathrm{C} 1$ to C9: $1.1 ; 0.4 ; 1.2 ; 16.9$; $2.7 ; 6.6 ; 4.9 ; 4.3$ and 4.3 respectively). Other important genera included Ammoniphilus and Paenibacillus.

Very diverse proteobacterial populations (172 genera in total) were present, but most comprised $<1 \%$ of reads. Nevertheless, three abundant and well-distributed genera were found: Balneimonas (now called Microvirga), Methylobacterium (both Methylobacteriaceae) and Sphingomonas (Springomonadaceae). Less abundant but well distributed were: Acidovorax, Afipia, Azospirillum (Beijerinckiaceae), Belnapia, Bosea, Bradyrhizobium, Burkholderia, Chelatococcus, Cystobacter, Duganella, Herbaspirillum, Janthinobacterium, Kaistobacter, Massilia (Oxalobacteraceae), Rhodomicrobium, Rubellimicrobium, Sinorhizobium, Sphingosinicella and Variovorax (various $\alpha$ - and $\beta$-Proteobacteria).

Other phyla that contained named genera included Bacteroidetes with Bacteroidaceae (Bacteroides) and Cytophagaceae (Adhaeribacter, Flexibacter, Hymenobacter and Sporocytophaga). Less abundant genera in the Flavobacteriaceae and Sphingobacteriaceae as well as Deinococcus (Deinococcus-Thermus) and Nitrospira (Nitrospirae) were also present. Other welldistributed genera included Acidimicrobia (Cyclobacteriaceae), Hymenobacter and Sporocytophyga (Flavobacteriaceae).

The Proteobacterial family Enterobacteriaceae contains a number of animal pathogens, some of which were occasionally found in most samples ( $<0.1 \%$ of reads): C1 had more Enterobacter, Escherichia and Shigella (but still less than 1\%) than the other samples. Klebsiella, Salmonella and Serratia were also present. Traces of the phytopathogen Erwinia were found in C1 as well as in C7-C9.

HtS techniques applied to DNA isolated from samples C3 and C5 allowed sequenced-based insights into the eukaryotes present (Figure 5). Amongst the fungi, Ascomycota were almost twice as abundant as Basidiomycota but traces of Chytridiomycota, Microsporidia and Glomeromycetes were also present. Bryozoa (aquatic, invertebrate animals) and Streptophyta (land plants and green algae) were also prevalent. Mollusca, which includes terrestrial representatives, was the other important group and a few green algae (see below) were also present.

\section{Living microorganisms}

Bacteria. In accordance with HtS data, samples C1 and C2 were poorer in bacteria than the others 
(Table 5). Both were collected at Bardaï, northern Chad (Figure 1, Table 1). Spores usually comprised $<30 \%$ of total colony-forming units (CFU), but bacteria that form an endospore were the dominant cultivable prokaryotes (see Table 5). Conversely, there were proportionally fewer Bacillaceae in Bodélé dust. It should not be forgotten however that Bacillaceae grow faster than other bacteria and it is thus difficult to isolate other genera in their presence. Thus the 'total numbers' presented here are estimates based on individual colonies that permits comparisons between comparable samples (for example, the sand samples, but not the dust). Nevertheless, half as many Bacillus spp. were present in the sands of Chad than were found aboard the 'Stad Amsterdam' (Table 6). Usually different species were present in the two locations, but B. pumilus and B. subtilis were found at both. The living bacterial population of Bodèlè dust was different from that found in the other locations. Only B. subtilis and Kocuria spp. (both environmental bacteria) were omnipresent. HtS data show that many environmental bacteria (anaerobic, autotrophic, photosynthetic and thermophilic) that cannot be isolated on standard media were present in the samples (Supplementary Tables 1 to 4), but unfortunately, the presence of intact DNA is not proof that the organism that furnished it is still alive.

Acacia spp., trees of the legume subfamily Mimosoideae, are a feature of African (and
Australian) deserts. To see if bacteria that provoke the formation of root nodules on legumes were present in the sands of Chad, we used selected African species of Acacia as 'traps' to isolate rhizobia (see Giongo et al., 2012). Bradyrhizobium spp., normal symbionts of Acacias (Dreyfus and Dommergues, 1981) were isolated this way. Diazotrophic Azospirillum spp. (Rhodospirillaceae) were also isolated. Use of a medium for the isolation of nitrifying bacteria permitted the cultivation of Nitrospira spp. HtS-based techniques confirmed the presence of all cultivable families but did not provide evidence for Agrobacterium, Exiguobacterium and Tsukamurella (cf Table 6, Supplementary Tables 1 to 4 ).

\section{Living fungi}

Although HtS-based methods showed that about half the fungi present in samples C3 and C5 were Basidiomycota, none were isolated in culture (Table 7). Common environmental genera like Aspergillus and Trichoderma were present along with the endophyte Fusarium equiseti (MaciaVicente et al., 2009). Only Cochliobolus lunatus was widespread. Whether or not a particular fungal species was present in a sample varied much more than with bacteria: most fungi were found in samples C3, C8 and C9. Interestingly, the only fungus found in Chad and on the 'Stad Amsterdam',

Table 4 Number of bacterial families and genera (grouped by Phylum) that make up $\geq 0.01 \%$ of total 'reads" in the nine samples of Chad sand

\begin{tabular}{|c|c|c|c|c|c|}
\hline Phylum & $\begin{array}{l}\text { Number of: } \\
\text { Families }\end{array}$ & Genera & $\begin{array}{c}\text { Number of reads: } \\
0.1-0.9 \%\end{array}$ & $\geqslant 1 \%$ & $\geqslant 1 \%$ in at least 3 samples \\
\hline Actinobacteria & 44 & 150 & 39 & 13 & 6 \\
\hline Acidobacteria & 3 & 17 & 8 & 0 & 0 \\
\hline Bacteroidetes & 8 & 29 & 13 & 5 & 2 \\
\hline Chloroflexi & 6 & 9 & 2 & 0 & 0 \\
\hline Deinococcus-Thermus & 2 & 2 & 0 & 1 & 1 \\
\hline Firmicutes & $1 \overline{5}$ & 44 & 25 & 4 & 1 \\
\hline Fusobacteria & 1 & 4 & 1 & 1 & 0 \\
\hline Gemmatimonadetes & 1 & 1 & 1 & 0 & 0 \\
\hline Nitrospirae & 1 & 2 & 1 & 0 & 0 \\
\hline Proteobacteria & 44 & 172 & 64 & 6 & 3 \\
\hline Planctomycetes & 1 & 10 & 1 & 0 & 0 \\
\hline Tenericutes & 2 & 2 & 1 & 0 & 0 \\
\hline Verrucomicrobia & 2 & 11 & 2 & 0 & 0 \\
\hline
\end{tabular}

Table 5 Numbers of viable bacteria in Chad sand samples estimated by culture-dependent methods

\begin{tabular}{|c|c|c|c|c|c|c|c|c|c|}
\hline & $C 1$ & C2 & C3 & $\begin{array}{l}\text { Bacteria }(C F U g \\
C 4\end{array}$ & -1) & C6 & $C 7$ & C8 & C9 \\
\hline Total \# OTU & $9 \times 10^{2}$ & $5.4 \times 10^{3}$ & $2.2 \times 10^{6}$ & $7.4 \times 10^{4}$ & $2.2 \times 10^{4}$ & $1.5 \times 10^{5}$ & $1.2 \times 10^{5}$ & $3.6 \times 10^{5}$ & $5.4 \times 10^{5}$ \\
\hline \# Total spores & $2.8 \times 10^{1}$ & $2.8 \times 10^{1}$ & $2.2 \times 10^{5}$ & $2 \times 10^{4}$ & $6.2 \times 10^{3}$ & $1.2 \times 10^{3}$ & $7 \times 10^{2}$ & $1.9 \times 10^{3}$ & $5.6 \times 10^{2}$ \\
\hline$\%$ spores & 3.1 & 0.5 & 10.0 & 27.0 & 28.2 & 0.8 & 0.6 & 0.5 & 0.1 \\
\hline \# OTU identified & 5 & 7 & 13 & 8 & 10 & 10 & 16 & 5 & 6 \\
\hline Location & Bardaï & Bahaï & Bardaï Wadi I & Bahaï Wadi II & Oure Cassoni & Ourba & Iriba & Ourba & Ourba \\
\hline
\end{tabular}

Abbreviation: OTU, operational taxonomic unit. 
Table 6 Living bacteria isolated by culture-dependent methods from sand and dust in Africa

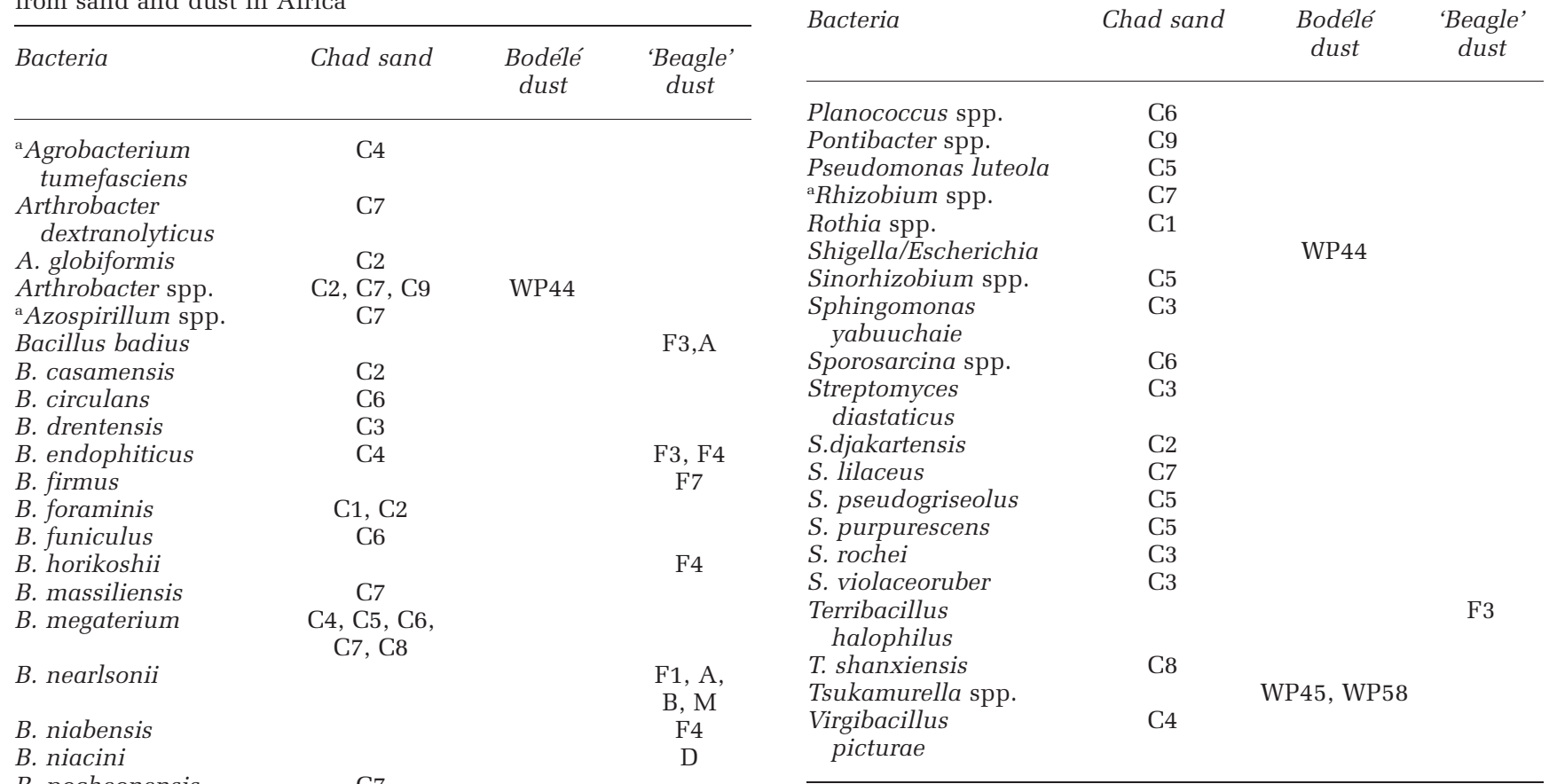

B. pocheonensis $\quad \mathrm{C7}$

B. pumilus $\quad \mathrm{C} 3 \quad \mathrm{~F} 2, \mathrm{~F} 4$

B. subtilis

B. thuringiensis

Bacillus spp.

Blastococcus spp.

${ }^{a}$ Bradyrhizobium spp.

Brevibacillus

borstelensis

Chelatococcus

asacharovorans

${ }^{a}$ Cohnella spp.

Cutobacterium

citreum

Curtobacterium spp.

Duganella violaceusniger

Exiguobacterium spp.

$\mathrm{C} 2, \mathrm{C} 3, \mathrm{C} 4, \mathrm{C} 5$,

WP44

C6, C7, C8, C9

C3

$\mathrm{C} 2$, C3, C5

C6, C7, C8

C4, C5, C7

WP44, WP58

WP58

C1

C9

C5

C3

C6, C7

C4, C5, C7

C5, C9

C5

C9

$\mathrm{C} 7$

C1

WP45, WP58
WP45

F4

WP58

F1, F2, F4

A, B, M

For abbreviations see Tables 1 to 3 .

a'Trapped' using leguminous plants as 'bait'. 'Beagle' dust means dust collected on board the 'Stad Amsterdam' that re-enacted the voyage of Charles Darwin's Beagle in 2009 (see Figure 1 and Table 3).

Cochliobolus lunatus, is possibly a pathogen of sugarcane.

Living algae

Algal isolates were obtained from samples C2, C3, C5 and C6. Morphological observations suggested that the isolates from $\mathrm{C} 2$ and $\mathrm{C} 3$ belonged to the Chlorella morphotype [cf Ettl, Gärtner (1995); John et al., 2002; Luo et al., 2010], whereas the isolates from C5 and C6 were similar to Haematococcus pluvinalis Flotow. Sequenced parts of the 3'-18 S rRNA gene and the entire internal transcribed spacer region supported the morphological observations. Isolate C2 was identical to that of C3 (both 97\% identity with Micractinium reisseri-Chlorellaceae, Trebouxiophyceae), the ‘European' algal symbiont of Paramecium bursaria (Hoshina et al., 2010). The internal transcribed spacer sequences of C5 and C6 were $98 \%$ similar to each other. The closest match in Genbank was GQ463618.1 that represents Haematococcus pluvialis strain $\mathrm{H}$ but they are not conspecific. Further work is required to assign the clones from Chad to a species of Haematococcus, as the phylogeny of this cosmopolitan group is unclear. The six species- $H$. buetschlii Blochmann, H. capensis Pocock, H. carocellus R.H.Thompson and D.E.Wujek, $H$. droebakensis Wollenweber, $H$. pluvialis Flotow and $H$. zimbabwiensis Pockock, are all freshwater inhabitants.

Microvirga spp.

Nitrospira multiformis

Nitrospira spp.

kribbensis

Oceanobacillus

picturae

humiphilum

Oxalobacteraceae
C7

$\mathrm{C} 4$

C4

C8
$P$. validus

Paenibacillus spp. 
Table 7 Living fungi isolated by culture-dependent methods from sand and dust in Africa

\begin{tabular}{|c|c|c|}
\hline Species from Chad sand & Sample & Classification (Family, Order, Phylum) \\
\hline Ampelomyces sp. & C9 & Leptosphaeriaceae; Pleosporales, Ascomycota \\
\hline Aspergillus flavus & C3 & mitosporic Trichocomaceae, Eurotiales, Ascomycota \\
\hline Aspergillus niger & C8 & mitosporic Trichocomaceae, Eurotiales, Ascomycota \\
\hline Capnobotryella sp. & $\mathrm{C} 2$ & Teratosphaeriaceae, Capnodiales, Ascomycota \\
\hline Cochliobolus lunatus & C3, C4, C7, C8, C9 & Pleosporaceae, Pleosporales, Ascomycota \\
\hline Eurotium chevalieri/amstelodamii & $\mathrm{C} 8$ & Trichocomaceae, Eurotiales, Ascomycota \\
\hline Exserohilum rostratum & C9 & Pleosporaceae, Pleosporales, Ascomycota \\
\hline Fusarium equiseti & C3 & Mitosporic Hypocreales, Ascomycota \\
\hline Fusarium sp. & C3, C9 & Mitosporic Hypocreales, Ascomycota \\
\hline Humicola fuscoatra & C9 & Mitosporic Ascomycota \\
\hline Myrothecium verrucaria & C8 & Mitosporic Hypocreales, Ascomycota \\
\hline Phoma macrostoma & C8 & Mitosporic Ascomycota \\
\hline Pleiochaeta ghindensis & C9 & Mitosporic Pezizomycotina, Ascomycota \\
\hline Teratosphaeria sp. & $\mathrm{C} 2$ & Teratosphaeriaceae, Capnodiales, Ascomycota \\
\hline Trichoderma inhamatum & C3 & Hypocreaceae, Hypocreales, Ascomycota \\
\hline Ulocladium sp. & C5 & Pleosporaceae, Pleosporales, Ascomycota \\
\hline Westerdykella nigra & $\mathrm{C} 7$ & Sporomiaceae, Pleosporales, Ascomycota \\
\hline Species from 'Beagle' dust & Sample & Taxonomic position \\
\hline Alternaria alternata & $\mathrm{F} 2$ & Pleosporales, Pleosporaceae, Ascomycota \\
\hline Bipolaris spicifera & F2 & Pleosporales, Pleosporaceae, Ascomycota \\
\hline Bipolaris spicifera or Cochliobolus australiensis & F3, F4 & Pleosporaceae, Pleosporales, Ascomycota \\
\hline Cladosporium sphaerospermum or Cladosporium lignicola & $\mathrm{F} 4, \mathrm{~F} 4$ & Davidiellaceae, Capnodiales, Ascomycota \\
\hline Cochliobolus lunatus or Macrophomina phaseolina & $\mathrm{F} 1, \mathrm{~F} 2, \mathrm{~F} 4, \mathrm{~F} 4$ & $\begin{array}{l}\text { Pleosporaceae, Pleosporales, Ascomycota or } \\
\text { Botryosphaeriaceae, Botryosphaeriales, Ascomycota }\end{array}$ \\
\hline Emericella nidulans or Emericella quadrilineata & F4 & Trichocomaceae, Eurotiales, Ascomycota \\
\hline Phoma betae or Macrophoma sp. & F2 & Mitosporic Ascomycota \\
\hline Phoma sp. & F2 & Mitosporic Ascomycota \\
\hline Thielavia arenaria or Thielavia subthermophila & $\mathrm{F} 2, \mathrm{~A}$ & Chaetomiaceae, Sordariales, Ascomycota \\
\hline
\end{tabular}

'Beagle' dust means dust collected on board the 'Stad Amsterdam' that re-enacted the voyage of Charles Darwin's Beagle in 2009 (Table 3).

HtS identified two phyla of Viridiplantae: Chlorophyta $(1.3 \%)$ and Charophyta $(0.2 \%)$. Two groups of Heterokontophyta-Bacilliarophyceae (diatoms) $(0.04 \%)$ as well as the family Chrysophyceae $(0.04 \%)$ were also present (Figure 5$)$.

Statistical correlations and dependencies. We assumed that specific microbes prefer certain environments. To test this, we calculated Spearman correlations between the concurrence of selected families and geographical parameters including altitude, latitude and longitude. The Cellulomonadaceae, Eubacteriaceae and Hyphomicrobiaceae were concentrated in eastern Chad whereas the Kineosporiaceae were mostly in the west (Figure 6). The Eubacteriaceae frequented lowlands. Cytophagaceae, the fourth most abundant family, correlated negatively with Clostridiaceae and Enterobacteriaceae that were positively associated. The fifth most abundant family Bacteroidaceae, correlated negatively with Bradyrhizobiaceae, Methylobacteriaceae and Sphingobacteriaceae.

Few correlations could be drawn between the mineral content of the sand and the bacterial inhabitants, but occurrence of the second most cosmopolitan family, the Sphingomonadaceae, was highly correlated with presence of $\mathrm{MgO}, \mathrm{Sr}, \mathrm{TiO}_{2}$ and
Zn (Figure 7). On the other hand, the sixth most abundant family, Geodermatophilaceae, was negatively correlated with the presence of $\mathrm{Ba}, \mathrm{K}_{2} \mathrm{O}, \mathrm{Pb}$ and $\mathrm{Rb}$. This contrasts with the Gemmatimonodaceae that seemed to have a preference for $\mathrm{Ba}, \mathrm{MgO}$ and $\mathrm{Rb}$.

Principal component analyses reduced the variables (operational taxonomic units (OTUs) and geographic location) to two principal components or axes F1 and F2 (Figure 8). Component F1 had the largest negative loadings from Acetobacteraceae, Cytophagaceae, Methylobacteriaceae, Rhodobacteraceae and so on, which are highly specialised environmental bacteria. Large positive loadings of component F1 came from Clostridiaceae, Coriobacteriaceae, Enterobacteriaceae, Veillonellaceae and so on, and animal-associated bacteria in eastern Chad. Component F2 had the largest negative loadings from Cellulomonadaceae, Eubacteriaceae, Gemmatimonadaceae, Hyphomicrobiaceae and so on, which were common in eastern Chad. The Kineosporiaceae, Lachnospiraceae and Ruminococcaceae caused large positive loadings on F2 that were associated with northwestern Chad and higher elevations. Some families that clustered strongly (long arrows) were abundant at C1, C2 and C5 but rare at other sites. Bacteroidaceae, Bifidobacteriaceae, Lachnospiraceae and Moraxellaceae were 


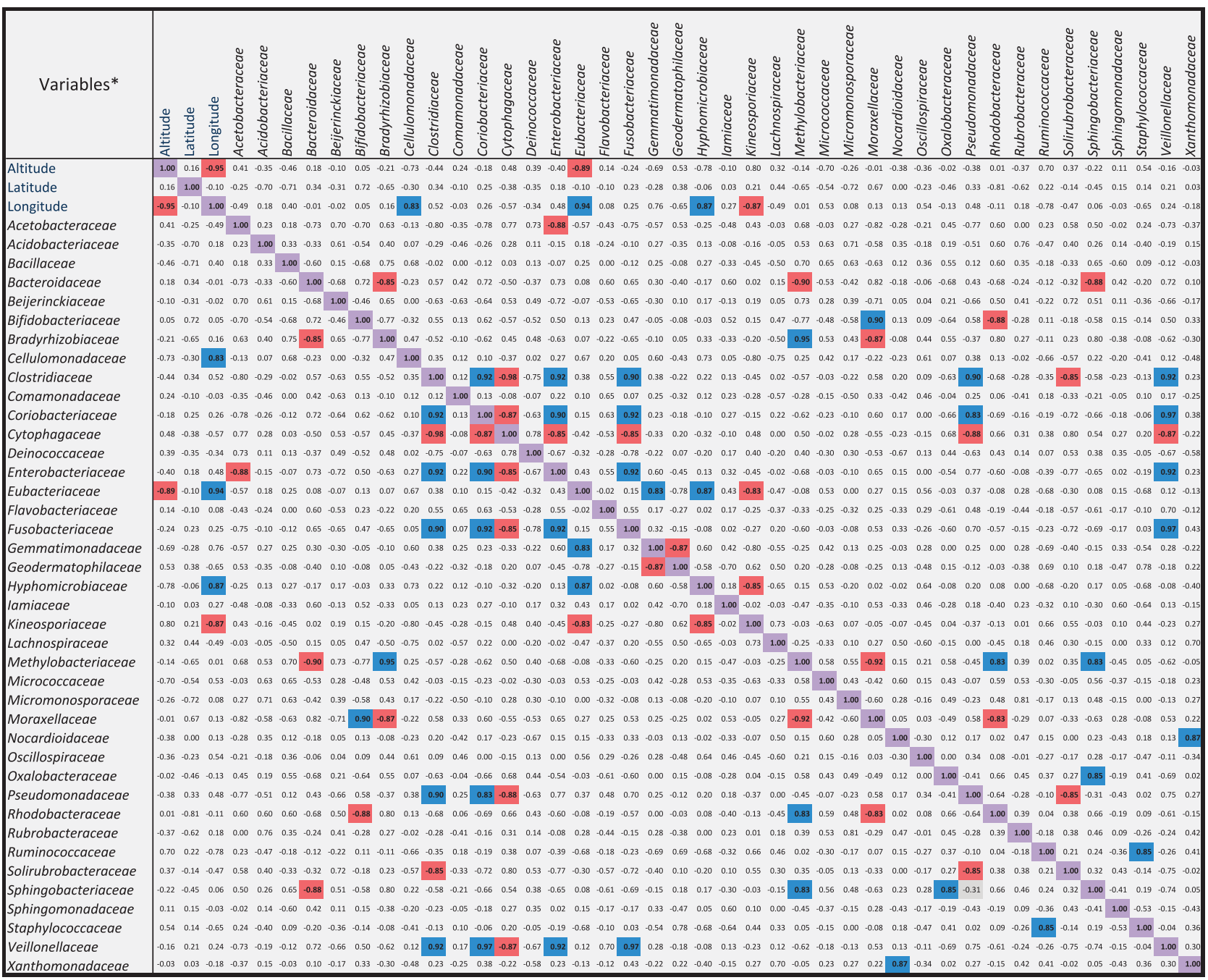

Values in bold are different from 0 with a significance level alpha=0.01

* Variables were stadardized $(\log 10)$

Figure 6 Spearman correlation matrixes between the 40 most abundant bacterial families detected by HtS methods as the principal variable with geographic coordinates and altitude as the supplementary variables. All variables were transformed using $\log _{10}$ to approximate a normal distribution. Red shading represents significant negative correlations; shading in blue signifies positive correlations $(\alpha<0.01)$. Note that the co-occurrence of some bacterial families is strongly positively or negatively correlated at the same location.

concentrated in central Chad. The Cellulomonadaceae, Eubacteriaceae, Gemmatimonadaceae clustered in eastern Chad. No particular family clustered at C3, C4, C6 and C7-9 (small arrows), indicating more random distributions.

\section{Discussion}

The Sahara, like other hot deserts of the intertropical zone, experiences temperatures up to $78{ }^{\circ} \mathrm{C}$, as many as 3250 sunshine hours per year and $<25 \mathrm{~mm}$ annual rainfall (Mainguet, 1995). Single daily variations in temperature of almost $40{ }^{\circ} \mathrm{C}$ (from -0.5 to $+37.5{ }^{\circ} \mathrm{C}$ ) have been recorded. Furthermore, the strong winds that are a feature of the Sahara mean that evaporation is greater than it would otherwise be. Merely to survive these extremes, desert dwelling microbes must possess a multitude of adaptations. Undoubtedly, this explains why up to $30 \%$ of living cells were in the form of spores (Table 5). We assume that most of the other living microbes were in a state of suspended animation that allows them to survive for extended periods (see Toepfer et al., (2012)).

Application of an array of techniques revealed predominantly environmental micro-organisms that were well adapted to the desert. In a similar study, Chanal et al. (2006) analysed 117 clones from the Tatouine desert in Southern Tunisia and found that the distribution of the main phyla (Actinobacteria and Proteobacteria) was similar to that reported here (Figure 4a-c). Many Actinomycetes (Actinobacteria) 
Variables

\section{율 «}

Acetobacteraceae $\quad \begin{array}{lllllllllllllllllllllllllllllll}0.28 & -0.20 & -0.40 & 0.10 & 0.32 & 0.20 & 0.24 & 0.18 & -0.52 & 0.18 & 0.27 & -0.04 & -0.32 & 0.27 & 0.06 & -0.24 & -0.51 & -0.13 & -0.02 & 0.03 & -0.66 & 0.26 & -0.30 & 0.08 & -0.25\end{array}$

$\begin{array}{llllllllllllllllllllllllllll}\text { Acidobacteriaceae } & 0.44 & -0.38 & 0.60 & 0.08 & 0.57 & 0.39 & 0.44 & 0.49 & 0.48 & 0.35 & 0.59 & 0.26 & 0.13 & 0.51 & 0.31 & 0.69 & 0.48 & -0.45 & 0.34 & 0.31 & 0.03 & 0.49 & 0.30 & 0.44 & 0.33\end{array}$ \begin{tabular}{l|lllllllllllllllllllllllllllllllllllllll} 
Bacillaceae & -0.17 & -0.33 & 0.15 & -0.64 & -0.31 & -0.47 & -0.26 & -0.28 & 0.07 & -0.52 & -0.15 & -0.57 & -0.37 & -0.33 & -0.60 & -0.01 & 0.10 & 0.35 & -0.44 & -0.50 & -0.47 & -0.37 & -0.20 & -0.40 & 0.05
\end{tabular}

\begin{tabular}{l|lllllllllllllllllllllllll} 
Bacteroidaceae & 0.37 & 0.40 & 0.33 & 0.44 & 0.03 & 0.02 & 0.04 & 0.13 & 0.37 & 0.24 & 0.13 & 0.13 & 0.48 & -0.08 & 0.09 & 0.33 & 0.39 & -0.23 & 0.27 & 0.27 & 0.74 & 0.10 & 0.50 & 0.27 & 0.40
\end{tabular}

\begin{tabular}{l|llllllllllllllllllllllllllllll} 
Beijerinckiaceae & 0.04 & -0.20 & -0.03 & 0.02 & 0.57 & 0.68 & 0.40 & 0.42 & -0.03 & 0.26 & 0.33 & 0.29 & -0.31 & 0.73 & 0.55 & 0.12 & -0.05 & -0.32 & 0.25 & 0.39 & -0.26 & 0.47 & 0.07 & 0.27 & 0.00
\end{tabular} \begin{tabular}{l|llllllllllllllllllllllllll} 
Bifidobacteriaceae & 0.05 & 0.54 & -0.13 & 0.20 & -0.11 & 0.20 & -0.07 & 0.03 & 0.07 & -0.05 & -0.30 & 0.29 & 0.13 & 0.02 & 0.28 & -0.15 & 0.04 & 0.03 & 0.03 & 0.15 & 0.63 & -0.01 & 0.20 & 0.00 & -0.07
\end{tabular} $\begin{array}{llllllllllllllllllllllllllllllllllllllll}\text { Bradyrhizobiaceae } & -0.20 & -0.52 & -0.05 & -0.59 & -0.08 & -0.05 & -0.20 & -0.18 & -0.07 & -0.25 & -0.07 & -0.35 & -0.58 & 0.07 & -0.13 & -0.05 & -0.08 & 0.23 & -0.23 & -0.22 & -0.61 & -0.18 & -0.28 & -0.27 & 0.05\end{array}$ $\begin{array}{llllllllllllllllllllllllllllllllll}\text { Cellulomonadaceae } & -0.05 & -0.14 & 0.32 & -0.54 & -0.34 & -0.27 & -0.24 & -0.43 & 0.35 & -0.39 & -0.27 & -0.51 & -0.18 & -0.14 & -0.29 & 0.11 & 0.38 & 0.28 & 0.01 & 0.00 & -0.18 & -0.48 & 0.20 & -0.35 & 0.42\end{array}$ $\begin{array}{llllllllllllllllllllllllllllll}\text { Clostridiaceae } & -0.17 & 0.52 & 0.13 & -0.08 & -0.40 & -0.28 & -0.20 & -0.27 & 0.18 & -0.49 & -0.42 & -0.35 & 0.03 & -0.37 & -0.28 & -0.03 & 0.22 & 0.32 & -0.16 & -0.07 & 0.26 & -0.38 & 0.22 & -0.37 & 0.25\end{array}$ \begin{tabular}{l|llllllllllllllllllllllllllllllll} 
Comamonadaceae & 0.05 & -0.36 & 0.13 & -0.38 & -0.61 & -0.60 & -0.73 & -0.60 & 0.18 & -0.13 & -0.30 & -0.41 & -0.03 & -0.60 & -0.36 & 0.07 & 0.15 & 0.40 & -0.18 & -0.35 & 0.11 & -0.59 & -0.17 & -0.30 & 0.35
\end{tabular} Coriobacteriaceae Cytophagaceae

Deinococcaceae Enterobacteriaceae $\begin{array}{llllllllllllllllllllllllllll}-0.05 & 0.64 & 0.15 & 0.13 & -0.22 & -0.20 & -0.07 & 0.00 & 0.17 & -0.37 & -0.20 & -0.28 & 0.08 & -0.31 & -0.29 & 0.04 & 0.22 & 0.13 & -0.21 & -0.08 & 0.42 & -0.14 & 0.32 & -0.18 & 0.25\end{array}$

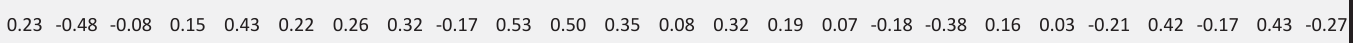
$\begin{array}{lllllllllllllllllllllllll}0.22 & -0.12 & -0.03 & 0.23 & 0.47 & 0.28 & 0.37 & 0.37 & -0.10 & 0.44 & 0.53 & 0.10 & 0.03 & 0.40 & 0.10 & 0.07 & -0.07 & -0.47 & 0.23 & 0.23 & -0.13 & 0.42 & 0.20 & 0.43 & 0.00\end{array}$

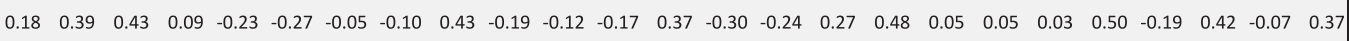
$\begin{array}{lllllllllllllllllllllllll}0.43 & -0.29 & 0.62 & -0.43 & -0.16 & 0.05 & -0.13 & -0.25 & 0.77 & -0.03 & -0.17 & 0.13 & 0.22 & 0.13 & 0.22 & 0.43 & 0.74 & 0.03 & 0.35 & 0.25 & 0.40 & -0.25 & 0.38 & 0.00 & 0.38\end{array}$ $\begin{array}{lllllllllllllllllllllllll}-0.13 & 0.17 & 0.18 & -0.12 & -0.39 & -0.38 & -0.47 & -0.32 & 0.17 & -0.31 & -0.20 & -0.64 & -0.22 & -0.45 & -0.36 & 0.17 & 0.18 & 0.32 & -0.21 & -0.13 & 0.11 & -0.40 & 0.13 & -0.33 & 0.67\end{array}$

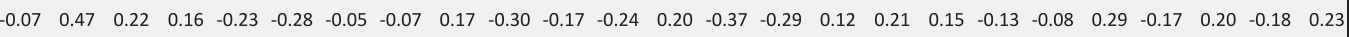
$\begin{array}{lllllllllllllllllllllllllll}0.62 & -0.31 & 0.85 & -0.14 & -0.04 & -0.13 & 0.02 & -0.13 & 0.85 & 0.19 & 0.17 & 0.06 & 0.55 & 0.01 & 0.01 & 0.67 & 0.87 & -0.18 & 0.48 & 0.27 & 0.45 & -0.13 & 0.53 & 0.22 & 0.55\end{array}$ $\begin{array}{llllllllllllllllllllllllllllll}-0.78 & 0.33 & -0.92 & 0.10 & -0.15 & -0.17 & -0.04 & -0.07 & -0.98 & -0.35 & -0.30 & -0.20 & -0.43 & -0.27 & -0.29 & -0.83 & -0.97 & 0.33 & -0.56 & -0.43 & -0.66 & -0.07 & -0.68 & -0.38 & -0.73\end{array}$

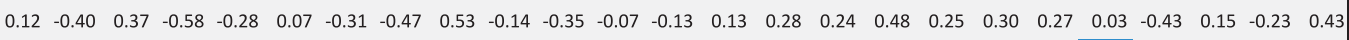
$\begin{array}{lllllllllllllllllllllllll}0.73 & 0.17 & 0.52 & 0.23 & 0.34 & 0.43 & 0.24 & 0.37 & 0.67 & 0.44 & 0.33 & 0.43 & 0.43 & 0.44 & 0.43 & 0.49 & 0.67 & -0.52 & 0.49 & 0.50 & 0.90 & 0.34 & 0.77 & 0.55 & 0.40\end{array}$

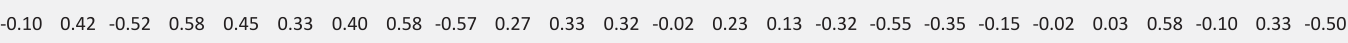
$\begin{array}{lllllllllllllllllllllllll}-0.07 & 0.58 & -0.38 & 0.54 & 0.39 & 0.38 & 0.47 & 0.58 & -0.38 & 0.11 & 0.15 & 0.50 & 0.13 & 0.24 & 0.23 & -0.28 & -0.37 & -0.28 & -0.13 & 0.02 & 0.24 & 0.54 & -0.03 & 0.27 & -0.60\end{array}$ $\begin{array}{llllllllllllllllllllllllllllll}-0.23 & -0.47 & -0.12 & -0.49 & 0.03 & 0.02 & -0.09 & -0.03 & -0.17 & -0.23 & 0.00 & -0.24 & -0.58 & 0.11 & -0.10 & -0.08 & -0.18 & 0.18 & -0.30 & -0.27 & -0.63 & -0.04 & -0.37 & -0.22 & -0.10\end{array}$ $\begin{array}{llllllllllllllllllllllllllll}0.07 & -0.65 & 0.37 & -0.62 & -0.19 & -0.18 & -0.22 & -0.27 & 0.35 & -0.24 & -0.15 & -0.07 & -0.15 & -0.08 & -0.07 & 0.26 & 0.31 & 0.27 & -0.09 & -0.23 & -0.26 & -0.27 & -0.23 & -0.23 & 0.07\end{array}$ $\begin{array}{lllllllllllllllllllllllllllll}0.28 & -0.05 & 0.35 & 0.06 & 0.45 & 0.10 & 0.49 & 0.53 & 0.18 & 0.06 & 0.53 & 0.04 & 0.10 & 0.23 & -0.20 & 0.32 & 0.25 & -0.38 & -0.07 & -0.08 & -0.05 & 0.45 & 0.23 & 0.32 & -0.05\end{array}$ $\begin{array}{llllllllllllllllllllllllll}0.22 & 0.36 & 0.07 & 0.21 & -0.20 & -0.03 & -0.11 & -0.10 & 0.22 & 0.07 & -0.23 & 0.29 & 0.43 & -0.15 & 0.14 & -0.02 & 0.20 & 0.00 & 0.15 & 0.12 & 0.69 & -0.11 & 0.23 & 0.07 & -0.02\end{array}$ $\begin{array}{lllllllllllllllllllllllllllllll}-0.08 & -0.08 & -0.02 & -0.21 & -0.08 & -0.02 & -0.02 & 0.05 & 0.00 & -0.28 & -0.22 & 0.24 & -0.07 & -0.08 & 0.03 & -0.06 & -0.03 & 0.20 & -0.30 & -0.32 & 0.00 & 0.00 & -0.32 & -0.17 & -0.40\end{array}$ $\begin{array}{lllllllllllllllllllllllllllll}0.07 & -0.23 & 0.16 & -0.68 & -0.38 & -0.07 & -0.51 & -0.40 & 0.37 & -0.32 & -0.38 & -0.30 & -0.41 & -0.05 & -0.01 & 0.04 & 0.33 & 0.33 & -0.13 & -0.08 & 0.12 & -0.45 & 0.10 & -0.31 & 0.37\end{array}$ $\begin{array}{llllllllllllllllllllllllllll}0.09 & -0.56 & -0.05 & -0.32 & -0.04 & -0.29 & -0.02 & -0.07 & -0.13 & 0.03 & 0.11 & 0.08 & 0.06 & -0.14 & -0.30 & -0.12 & -0.13 & 0.02 & -0.21 & -0.44 & -0.34 & -0.03 & -0.38 & 0.03 & -0.50\end{array}$ $\begin{array}{lllllllllllllllllllllllll}-0.27 & 0.48 & -0.07 & -0.32 & -0.60 & -0.42 & -0.40 & -0.40 & 0.05 & -0.68 & -0.62 & -0.43 & -0.15 & -0.51 & -0.44 & -0.28 & 0.08 & 0.50 & -0.43 & -0.33 & 0.21 & -0.54 & 0.03 & -0.53 & 0.03\end{array}$ $\begin{array}{llllllllllllllllllllllllll}0.06 & -0.79 & 0.18 & -0.39 & 0.04 & -0.16 & -0.15 & -0.08 & 0.06 & 0.07 & 0.23 & -0.17 & -0.24 & -0.01 & -0.13 & 0.24 & 0.03 & 0.05 & -0.09 & -0.24 & -0.50 & -0.04 & -0.32 & -0.02 & 0.10\end{array}$ $\begin{array}{lllllllllllllllllllllllllll}0.63 & -0.26 & 0.55 & 0.02 & 0.53 & 0.34 & 0.46 & 0.59 & 0.51 & 0.30 & 0.54 & 0.47 & 0.28 & 0.45 & 0.21 & 0.54 & 0.52 & -0.50 & 0.17 & 0.09 & 0.34 & 0.54 & 0.33 & 0.52 & -0.02\end{array}$

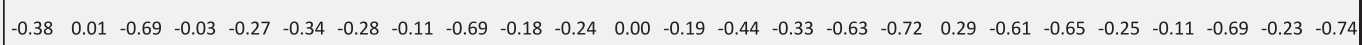
\begin{tabular}{l|lllllllllllllllllllllllll} 
Solirubrobacteraceae & 0.33 & -0.30 & -0.03 & 0.31 & 0.66 & 0.68 & 0.42 & 0.55 & -0.02 & 0.65 & 0.52 & 0.67 & 0.07 & 0.69 & 0.69 & 0.20 & -0.07 & -0.53 & 0.38 & 0.38 & 0.08 & 0.65 & 0.03 & 0.58 & -0.17
\end{tabular}

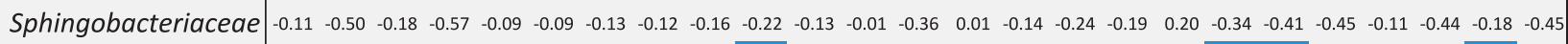
\begin{tabular}{l|llllllllllllllllllllllllll} 
Sphingomonadaceae & 0.73 & -0.01 & 0.48 & 0.68 & 0.67 & 0.60 & 0.60 & 0.50 & 0.48 & 0.93 & 0.68 & 0.68 & 0.75 & 0.66 & 0.68 & 0.59 & 0.49 & -0.82 & 0.94 & 0.85 & 0.61 & 0.62 & 0.70 & 0.85 & 0.33
\end{tabular} $\begin{array}{lllllllllllllllllllllllllllllllllllll}\text { Staphylococcaceae } & -0.56 & 0.07 & -0.65 & -0.03 & -0.39 & -0.63 & -0.26 & -0.24 & -0.78 & -0.37 & -0.28 & -0.29 & -0.16 & -0.67 & -0.66 & -0.67 & -0.76 & 0.41 & -0.69 & -0.77 & -0.52 & -0.26 & -0.74 & -0.39 & -0.71\end{array}$ $\begin{array}{llllllllllllllllllllllllllllllllll}\text { Veillonellaceae } & -0.08 & 0.56 & 0.20 & 0.16 & -0.24 & -0.27 & -0.09 & -0.07 & 0.17 & -0.33 & -0.17 & -0.35 & 0.12 & -0.36 & -0.32 & 0.11 & 0.22 & 0.15 & -0.14 & -0.05 & 0.32 & -0.18 & 0.28 & -0.20 & 0.35\end{array}$

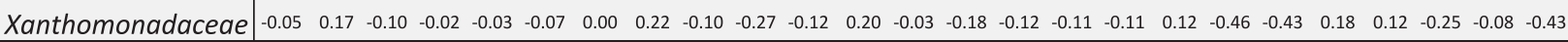

Values in bold are different from 0 with a significance level alpha $=0.01$

* Variables were stadardized ( $\log 10)$

Figure 7 Spearman correlation matrix between the 40 most abundant bacterial families detected by HtS methods as the principal variable and geochemical attributes as the supplementary variable. All variables were transformed using $\log _{10}$ to approximate a normal distribution. Red shading represents significant negative correlations; shading in blue signifies positive correlations $(\alpha<0.01)$. 
Variables (axes F1 and F2: $58 \%$ )

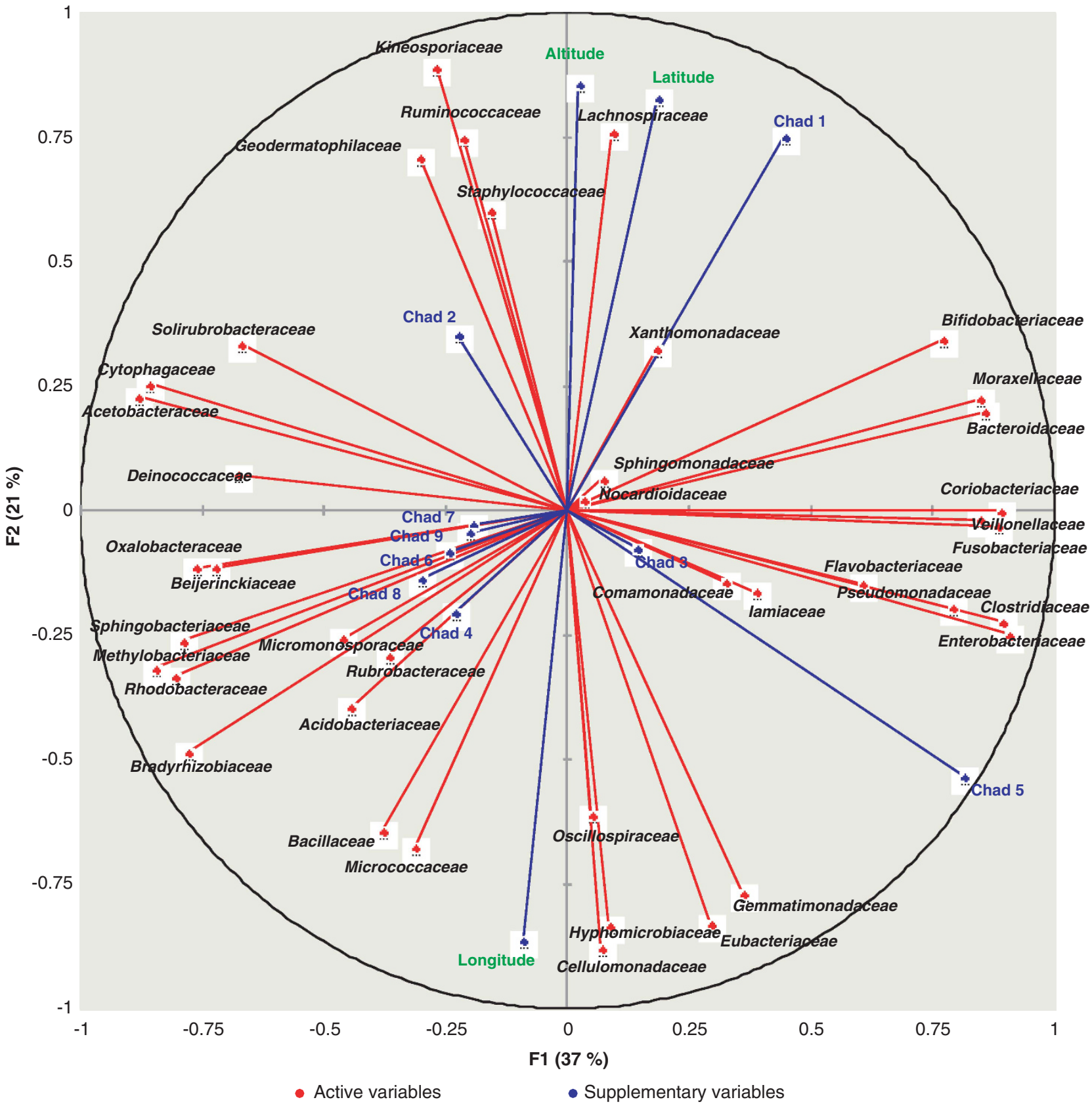

Figure 8 Principal component analyses were performed on the $\log _{10}$ transformed Spearman rank correlation matrices and used to cluster the 40 most abundant bacterial families found by HtS based methods with the geographical coordinates (altitude, latitude and longitude) of the places where samples C1-C9 were collected (see Table 1). Longer vectors indicate a larger contribution of the variable whereas the closer the variables are to one another, the higher the correlation between them.

and Crenarchaeota were present in the Tatouine along with most Proteobacterial groups $(\alpha, \gamma, \delta$ and $\varepsilon)$. Most probably the differences are not significant, but the diversity of Acidobacteria was greater in the Tatouine whereas more Firmicutes were found in Chad. As many Firmicutes readily form spores, this may imply higher efficiency of DNA extraction (Giongo et al., 2012). Obviously, the greater depth of sequencing used here helped reveal more phyla in Chad-of the 59 genera identified by Chanal et al.
(2006), only 19 were not found. Both analyses identified many bacteria that are resistant to radiation and/or desiccation.

Most concerns about the spread of human diseases revolve around the Proteobacterial family Enterobacteriaceae that contains the pathogenic genera Enterobacter, Escherichia, Klebsiella, Salmonella, Serratia and Shigella. Despite the proximity of a garrison near C1 and C2 or refugee camps near C5, none of these species were abundant $(<0.1 \%$ total 
reads). Traces of Erwinia spp. were present in C4, C6, C7, C8 and C9. Enterobacteriaceae were presumably of human origin and therefore not able to survive long as they are strangers to the desert niche as well as inherently poor survivors in sand (see Toepfer et al., (2012)). In any event, most introduced microorganisms quickly succumb to competition with normal soil inhabitants and may also be engulfed by protozoa (Prescott et al., 2003).

Most mycobacteria are non-pathogenic, soil bacteria from which infectious species such as $M$. tuberculosis and $M$. leprae probably evolved. It is thus neither alarming nor surprising that Mycobacterium spp. were found in almost all samples (frequency $\sim 0.1 \%$ ). Similarly, environmental genera that contain opportunistic pathogens were present including Alcaligenes, Brevundimonas, Massilia, Nocardiopsis and Sphingomonas. Other environmental genera including Aurantimonas, Clavibacter, Leifsonia, Sphingomonas and Xanthomonas, that despite taxonomic uncertainties, may include potential plant pathogens, were also present. All members of the family Bacillaceae form endospores and some of them are animal pathogens. Since HtS methods did not permit assigning bacteria to a species, it is possible that $B$. anthracis was present in some of the samples.

Obvious environmental adaptations included various pigments that protect the desert consortia from: (a) solar radiation; (b) high temperatures including a number of Actinobacteria-Pseudonocardia (Pseudonocardiaceae) and Streptomyces (Streptomycetaceae); Thermomonosporaceae as well as other groups like Alterococcus, Nitrospira, Porphyrobacter and Rubellimicrobium. The Geobacteraceae includes both thermophilic and psychrophilic species. Geobacter stearothermophilus is even used to check autoclaves; (c) $\gamma$ radiation especially in Deinococcus, Hymenobacter, Kineococcus, Methylobacterium and Rubrobacter; (d) desiccation (often associated with resistance to radiation) for example, in Arthrobacter, Candidatus-Solibacter, Corallococcus, Kineococcus and Methylobacterium; (e) psychrotolerance (a characteristic of Antarctic bacteria but also necessary at night in the Sahara) in Frigobacterium, Planococcus, Subtercola, some Rhodobacteraceae (Antarctic inhabitants), Modestobacter (also Antarctic) (Hirsch et al., 2004a, b) and (f) halophyly in Alterococcus, Salinarimonas, and Nocardioides ( $N$. halotolerans survives $1.7 \mathrm{M} \mathrm{NaCl}$ ). Developmental adaptations (for example, spore formation) are prevalent in the Bacillaceae/Paenibacillaceae: for this reason they are widespread, diverse and numerous. Indeed, Bacillus subtilis is ecumenical in the sands and dust of Chad.

Cytophagaceae, a family that contains many marine bacteria (often associated with fish such as Flexibacter or Flectobacillus) were abundant. Some marine Actinobacteria (Salinispora and Verrucosispora) were also present. Other species linked to aquatic life, some of them motile including: (a)
Actinobacteria-Cryptosporangium, Nocardioides and Sporichthya (motile spores); (b) Proteobacteria-Chelatococcus (Beijerinckiaceae), Haliangiaceae, some Rhodoplanes (Hyphomicrobiaceae), Roseomonas (Acetobacteraceae) and Skermanella (Rhodospirillaceae); (c) many Rhodocyclaceae, Rhodospirillaceae and Sphingomonadaceae, and (d) Planctomycetaceae were also found. It is not clear whether these aquatic, mobile species adapted to desert conditions including higher salt concentrations as Mega-Lake Chad dried out or are special desert forms of aquatic relatives, because HtS-based techniques do not yield a living organism for further study. Motile bacteria that associate with the roots of plants like Herbaspirillum and Mesorhizobium (respectively $\beta$ - and $\alpha$-Proteobacteria) were also present.

The oligotrophic families Geodermatophilaceae, Pseudonocardiaceae, Rhodocyclaceae and Rubrobacteraceae were particularly abundant. Most bacteria found were aerobic but strict anaerobes including members of the Clostridiaceae, Fusobacteriaceae, Geobacteraceae, Lactobacillaceae, Oxalobacteraceae, Opitutaceae and Rhodospirillaceae were present. Facultative anaerobes including the Enterobacteriaceae, Myxococcaceae, some Opitutaceae and Rhodospirillaceae were found along with Rhodomicrobium.

A few thermophilic and anaerobic methanogens (Euryarchaeota) belonging to the family Methanothermaceae (Methanobacteriales) were found especially in C1 and C2. The proteobacterial family Methylobacteriaceae (Rhizobiales) includes numerous Methylobacterium and Microvirga: some of the latter can reduce nitrogen gas to ammonia (Ardley et al., 2012). Methanol and other carbon compounds are used for growth. Methanotrophic Methylocystaceae ( $\alpha$-Proteobacteria, Rhizobiales) that obtain energy from methane and fix nitrogen were found. Many other bacteria that can fix nitrogen under freeliving conditions or in association with plants including Beijerinckiaceae, Bradyrhizobiaceae and Rhizobiaceae (Rhizobiales), some Mesorhizobium (Phyllobacteraceae), Azospirillum and Rhodospirillum (Rhodospirillaceae), Frankia (Actinobacteria, Frankiaceae) and Herbaspirillum (Oxalobacteraceae) were present. In general the Beijerinckiaceae fix nitrogen under free-living conditions whereas Bradyrhizobium, Frankia, Mesorhizobium and Rhizobium are symbionts of plants. This abundance of nitrogen-fixing bacteria highlights the scarcity of nitrogenous compounds in the deserts of Chad.

Heterotrophy was not the only life style observed. Members of the families Desulfurococcaceae and Sulfolobaceae (Crenarchaeota) are normally thermophilic and use sulphur either for anaerobic respiration or as a source of energy (Desulfurococcaceae). Photoheterotrophic $\alpha$-Proteobacteria that require organic carbon under anoxic conditions in light include Blastochloris, Rhodomicrobium, Rhodoplanes (all Hyphomicrobiaceae) and some 
Rhodobacteraceae. Other families containing photoheterotrophic bacteria include the Rhodobiaceae, Rhodocyclaceae and Rhodospirillaceae. Bacteria that can be photoheterotrophic under aerobic conditions included Paracraurococcus, Porphyrobacter and some Sphingomonas (all Proteobacteria).

That biodegradation is an important aspect of microbial life in deserts is shown by the abundance of Actinobacteria, many of which are capable of efficiently hydrolysing cellulose and lignin (for example, Cellulosimicrobium and Isoptericola). Other bacteria able to digest plant material were found (Cystobacteraceae, Cytophagaceae and Polyangiaceae) along with many others that can degrade complex organic compounds including synthetic molecules.

Members of Geodermathophilaceae were described from desert rocks and soils (Hungate et al., 1987; Eppard et al., 1996; Garrity et al., 1996); they are also associated with degradation of carbonaceous monuments (Urzi and Realini, 1998; Urzì et al., 2001). Black pigmented Geodermatophilaceae show high stress resistances, including to massive doses of $\gamma$ radiation (30 kGy) that is comparable to levels tolerated by Deinococcus radiodurans (Rainey et al., 1995).

Fungal isolates represent a random collection of mostly dark pigmented spore-forming fungi. With the exception of Cochliobolus lunatus, which was frequently present, most isolates were found in only one sample. Data from HtS reflect the relatively poor representation of fungi in molecular data databases. No doubt fungal spores can travel with dust clouds and have a role in respiratory illness. However, all attempts to isolate rock-inhabiting and/or desiccation-tolerant fungi (such as microcolonial fungi sensu Staley et al., 1982) delivered only small black colonies of the bacterium Geodermatophilus obscurus.

All algal isolates belonged to the class Trebouxiophyceae (Figure 5), well known for its terrestrial members (Friedl, 1995). Ha. pluvialis produces astaxanthin that protects the photosynthetic apparatus from photo-oxidative damage (under high light intensities) or nutrient stresses (Vidhyavathi et al., 2008). HtS showed that members of the Ulvophyceae, Chlorophyceae, Charophyceae, Prasinophyceae, Zygnemophyceae, Bacillariophyceae and Chrysophyceae were also present, but they may have been dormant and thus not observed in culture.

The microbial catalogue of dust collected onboard the 'Stad Amsterdam' in the Cape Verde Islands was similar to that found in the sands of Chad. In contrast, dust from the Bodélé Depression had fewer Bacilli. Part of this difference is undoubtedly traceable to varying soil types-the Bodélé Depression was once part of Mega-Lake Chad. As a consequence, the lake sediments are rich in calcium whereas the desert sands are siliceous. Furthermore, it is conceivable that constant erosion in the Bodélé Depression restricts the establishment of some bacterial populations and blows away bacterial spores. Nevertheless with only one exception, all bacteria isolated from the Bodélé Depression were also found using HtS methods in other parts of Chad. This strongly suggests that the microbial populations are similar but that saltation alters their occurrence.

Shinn et al. (2000) suggested that dust from Africa carried Aspergillus sydowii to the Caribbean where it caused the demise of coral reefs. We showed that $A$. sydowii remains viable even after extended storage periods on dry sand (Toepfer et al., 2012). However, even though we found $A$ flavus and $A$. niger in two samples of Chad sand, A. sydowii was not present (Table 7). Furthermore, Aspergillus spp. were not present in the dust collected aboard the 'Stad Amsterdam'. Rypien (2008) collected air samples in Mali during three dust storms (as well as one in St. Croix (Caribbean)) and isolated several Aspergillus spp. but not A. sydowii. Absence of A. sydowii is not proof that it does not occur in Africa nor should it be forgotten that dust clouds are dynamic ecosystems that can gain and lose hitchhikers as they pass over land and sea (Griffin, 2007). In other words, our results primarily describe the microbial load at the point of departure but they do not measure changes that may occur as the dust clouds move around the planet.

In summary, most hitchhikers on desert dust are environmental microbes that are well adapted to the harsh conditions. These same adaptations help them survive intercontinental travel. If contamination occurs at the source, pathogens can accompany the desert dwellers but are less likely to survive the journey.

\section{Conflict of Interest}

The authors declare no conflict of interest.

\section{Acknowledgements}

We would especially like to thank Dr Agathe Stricker of the International Committee of the Red Cross in Geneva, Switzerland for organising the collection of the 'Sandman' samples from the Republic of Chad. On board the Stad Amsterdam, Ilja Willems and Kapitein Richard Slootweg were particularly helpful. We thank Dora Gerber, Michal Parkan, Xavier Perret, Wolfgang Streit and Luiz Roesch for their unstinting help. Dyson Ltd, Tetbury Hill Malmesbury Wiltshire SN16 0RP, UK generously donated a hand-held vacuum cleaner. We relied heavily on Wikipedia (in three languages) and Genoscope to accurately place bacteria and their metabolisms. In Switzerland, the work was supported by the Fonds National Suisse de la Recherche Scientifique (Projects 3100AO-104097 and 3100A0-116858), the Département de l'Instruction Publique du Canton de Genève and the Université de Genève. Work in the United States of America was made possible by grants from the National Science Foundation (Grant Number MCB-0454030) and the United States Department of Agriculture (Grant Numbers 2005-35319-16300, 00067345). 


\section{References}

Alfaro SC, Gaudichet A, Gomes L, Maille M. (1998). Mineral aerosol production by wind erosion: aerosol particle sizes and binding energies. Geophys Res Lett 25: 991-994.

Ardley JK, Parker MA, De Meyer SE, Trengove RD, O’Hara GW, Reeve WG et al. (2012). Microvirga lupini sp. nov. Microvirga lotononidis sp. nov. And Microvirga zambiensis sp. nov. are alphaproteobacterial root-nodule bacteria that specifically nodulate and fix nitrogen with geographically and taxonomically separate legume hosts. Int J Syst Evol Microbiol 62: 2579-2588.

Bristow CS, Hudson-Edwards KA, Chappell A. (2010). Fertilizing the Amazon and equatorial Atlantic with West African dust. Geophys Res Lett 37: 3-7.

Callot Y, Marticorena B, Bergametti G. (2000). Geomorphologic approach for modelling the surface features of arid environments in a model of dust emissions: application to the Sahara desert. Geodinamica Acta 13: $246-270$.

Caquineau S, Gaudichet A, Gomes L, Magonthier M-C, Chatenet B. (1998). Saharan dust: clay ration as a relevant tracer to assess the origin of soil-derived aerosols. Geophys Res Lett 25: 983-986.

Chanal A, Chapon V, Benzerara K, Barakat M, Christen R, Achouak W et al. (2006). The desert of Tataouine: an extreme environment that hosts a wide diversity of microorganisms and radiotolerant bacteria. Environ Microbiol 8: 514-525.

Chappell A, Warren A, O'Donoghue A, Robinson A, Thomas A, Bristow C. (2008). The implications for dust emission modeling of spatial and vertical variations in horizontal dust flux and particle size in the Bodele Depression, Northern Chad. J Geophys Res 113: D04214.

Collaud Coen M, Weingartner E, Schaub D, Hueglin C, Corrigan C, Schwikowski M et al. (2003). Saharan dust events at the Jungfraujoch: detection by wavelength dependence of the single scattering albedo and analysis of the events during the years 2001 and 2002. Atmos Chem Phys Discuss 3: 5547-5594.

Darwin CR. (1846). An account of the fine dust which often falls on vessels in the Atlantic Ocean. QJ Geol Soc London 2 (Read 4 June 1845), 26-30. http://darwinonline.org.uk/content/frameset?itemID=F1672\&view type $=$ side $\&$ pageseq $=1$.

Drake N, Bristow CS. (2006). Shorelines in the Sahara: Geomorphological evidence for an enhanced monsoon from palaeolake Megachad. Holocene 16: 901-911.

Dreyfus BL, Dommergues YR. (1981). Nodulation of Acacia species by fast- and slow-growing tropical strains of Rhizobium. Appl Environ Microbiol 41: 97-99.

Engelstaedter S, Tegen I, Washington R. (2006). North African dust emissions and transport. Earth Sci Rev 79: $73-100$.

Eppard M, Krumbein WE, Koch C, Rhiel E, Staley JT, Stackebrandt E. (1996). Morphological, physiological, and molecular characterization of actinomycetes isolated from dry soil, rocks, and monument surfaces. Archiv. Microbiol 166: 12-22.

Ettl H, Gärtner G. (1995). Syllabus der Boden-, Luft- und Flechtenalgen. Gustav Fischer Verlag: Stuttgart, 721pp.

Friedl T. (1995). Inferring taxonomic positions and testing genus level assignments in coccoid green algae: a phylogenetic analysis of $18 \mathrm{~S}$ ribosomal RNA sequences from Dictyochloropsis reticulata and from members of the genus Myrmecia (Chlorophyta, Trebouxiophyceae cl. nov.). J Phycol 31: 632-639.

Garrity GM, Heimbuch BK, Gagliardi M. (1996). Isolation of zoosporogenous actinomycetes from desert soils. J Ind Microbiol 17: 260-267.

Giles J. (2005). The dustiest place on Earth. Nature 434: 816-819.

Giongo A, Favet J, Lapanje A, Gano KA, Kennedy S, Brown C et al. (2012). Microbial hitchhikers on intercontinental dust: high-throughput sequencing to catalogue microbes in small sand samples. Aerobiologia (in press).

Gorbushina AA, Kort R, Schulte A, Lazarus D, Schnetger B, Brumsack H-J et al. (2007). Life in Darwin's dust intercontinental transport and survival of microbes in the nineteenth century. Environ Microbiol 9: 29112922.

Goudie AS, Middleton NJ. (2001). Saharan dust storms: nature and consequences. Earth Sci Rev 56: 179-204.

Goudie AS, Middleton NJ. (2006). Desert Dust in the Global System. Springer: Heidelberg, 288pp.

Griffin DW. (2007). Atmospheric movement of microorganisms in clouds of desert dust and implications for human health. Clin Microbiol Rev 20: 459-477.

Griffin DW, Kellogg C, Shinn E, Gray M, Garrison G. (2003a). U.S. Geological Survey, St. Petersburg, Florida, Desert Storms and their ability to move microorganisms and toxins around the globe. http://www.cprm.gov.br/pga gem/puerto/MedGeo.Griffin.pdf.

Griffin DW, Kellogg CA, Garrison VH, Lisle JT, Borden TC, Shinn EA. (2003b). African dust in the Caribbean atmosphere. Aerobiologia 19: 143-157.

Hirsch P, Gallikowski CA, Siebert J, Peissl K, Kroppenstedt R, Schumann P et al. (2004a). Deinococcus frigens sp nov, Deinococcus saxicola sp nov., and Deinococcus marmoris sp nov, low temperature and draughttolerating, UV-resistant bacteria from continental Antarctica. Syst Appl Microbiol 27: 636-645.

Hirsch P, Mevs U, Kroppenstedt RM, Schumann P, Stackebrandt E. (2004b). Cryptoenclolithic actinomycetes from antarctic sandstone rock samples: Micromonospora endolithica sp nov and two isolates related to micromonospora coerulea Jensen 1932. Systematic \& Appl. Microbiol 27: 166-174.

Hoshina R, Iwataki M, Imamura N. (2010). Chlorella variabilis and Micractinium reisseri sp. nov. (Chlorellaceae, Trebouxiophyceae): Redescription of the endosymbiotic green algae of Paramecium bursaria (Peniculia, Oligohymenophorea) in the 120th year. Phycol Res 58: 188-201.

Hungate B, Danin A, Pellerin NB, Stemmler J, Kjellander $\mathrm{P}$, Adams JB et al. (1987). Characterization of manganese-oxidizing (MnII-MnIV) bacteria from Negev desert rock varnish - implications in desert varnish formation. Canadian J Microbiol 33: 939-943.

John DM, Whitton BA, Brook AJ (Eds.) (2002). The Freshwater Algal Flora of the British Isles. An Identification Guide To Freshwater and Terrestrial Algae. Cambridge University Press: Cambridge, pp 714.

Kellogg CA, Griffin DW. (2006). Aerobiology and the global transport of desert dust. Trends Ecol Evol 21: 638-644.

Kellogg CA, Griffin DW, Garrison VH, Peak KK, Royall N, Smith RR et al. (2004). Characterization of aerosolized bacteria and fungi from desert dust events in Mali, West Africa. Aerobiologia 20: 99-110. 
Koren I, Kaufman YJ, Washington R, Todd MC, Rudich Y, Martins JV et al. (2006). The Bodele Depression: a single spot in the Sahara that provides most of the mineral dust to the Amazon forest. Environ Res Lett 1 (2006) 014005 (5pp).

Kröpelin S, Verschuren D, Lézine AM, Eggermont H, Cocquyt C, Francus P et al. (2008). Climate-driven ecosystem succession in the Sahara: the past 6000 years. Science 320: 765-768.

Lim N, Munday CI, Allison GE, O’Loingsigh T, De Deckker P, Tapper NJ. (2011). Microbiological and meteorological analysis of two Australian dust storms in April 2009. Sci. Total Environ 412-413: 223-231.

Luo W, Proschold T, Bock C, Krienitz L. (2010). Generic concept in Chlorella-related coccoid green algae (Chlorophyta, Trebouxiophyceae). Plant Biol 12: 545-553.

Macia-Vicente JG, Rosso LC, Ciancio A, Jansson H-B, Lopez-Llorca LV. (2009). Colonisation of barley roots by endophytic Fusarium equiseti and Pochonia chlamydosporia: effects on plant growth and disease. Ann Appl Biol 155: 391-401.

Mainguet M. (1995). "L' homme et la seécheresse». Masson: Paris 335. pp Prescott (Prescott p. 623).

Middleton JJ, Goudie AS. (2001). Saharan dust: sources and trajectories. Trans Inst Br Geogr NS 26: $165-181$.

Prescott LM, Harley JP, Klein DA. (2003). Microbiologie, 2nd French edn. Editions De Boeck Université: Bruxelles, pp. 668-696 (Chapter 30).

Prospero JM, Blades E, Mathison G, Naidu R. (2005). Interhemispheric transport of viable fungi and bacteria from Africa to the Caribbean with soil dust. Aerobiologica 21: 1-19.

Rainey FA, Ray K, Ferreira M, Gatz BZ, Nobre F, Bagaley D et al. (2005). Extensive diversity of ionizing-radiationresistant bacteria recovered from Sonoran desert soil and description of nine new species of the genus Deinococcus obtained from a single soil sample. Appl Environ Microbiol 71: 7630-7630.
Rypien KL. (2008). African dust is an unlikely source of Aspergillus sydowii, the causative agent of sea fan disease. Mar Ecol-Progr Ser 367: 125-131.

Shinn EA, Smith GW, Prospero JM, Betzer P, Hayes ML, Garrison VH et al. (2000). African dust and the demise of Caribbean coral reefs. Geol Res Lett 27: 3029-3032.

Shao Y-P. (2008). Physics and Modelling of Wind Erosion Springer Science + Business Media B.V, 452pp.

Shao Y-P, Wyrwoll K-H, Chappell A, Huang J-P, Lin Z-H, McTainsh G et al. (2011). Dust cycle: an emerging core theme in earth system science. Aeolian Res 2: 181-204.

Staley JT, Palmer F, Adams JB. (1982). Microcolonial fungi: common inhabitants on desert rocks? Science 215: 1093-1095.

Toepfer I, Favet J, Schulte A, Schmölling M, Butte W, Triplett EW et al. (2012). Pathogens as potential hitchhikers on intercontinental dust. Aerobiolgia 28: 221-231.

Urzì C, Brusetti L, Salamone P, Sorlini C, Stackebrandt E, Daffonchio D. (2001). Biodiversity of Geodermatophilaceae isolated from altered stones and monuments in the Mediterranean basin. Environ Microbiol 3: 471-479.

Urzi C, Realini M. (1998). Colour changes of Noto's calcareous sandstone as related to its colonisation by microorganisms. Int Biodeter Biodegr 42: 45-54.

Vidhyavathi R, Venkatachalam L, Sarada R, Ravishankar GA. (2008). Regulation of carotenoid biosynthetic genes expression and carotenoid accumulation in the green alga Haematococcus pluvialis under nutrient stress conditions. J Exp Bot 59: 1409-1418.

Warren A, Chappell A, Todd MC, Bristow C, Drake N, Engelstaedter S et al. (2007). Dust-raising in the dustiest place on earth. Geomorphology 92: 25-37.

Weir-Brush JR, Garrison VH, Smith GW, Shinn EA. (2004). The relationship between gorgonian coral (Cnidaria: Gorgonacea) diseases and African dust storms. Aerobiologia 20: 119-126.

Yamaguchi N, Ichijo T, Sakotani A, Baba T, Nasu M. (2012). Global dispersion of bacterial cells on Asian dust. Sci Rep 2: 0525.

Supplementary Information accompanies the paper on The ISME Journal website (http://www.nature.com/ismej) 